Discussion Paper No. 16-021

\title{
Philanthropy in a Secular Society
}

Benjamin Bittschi, Sarah Borgloh, and Berthold U. Wigger

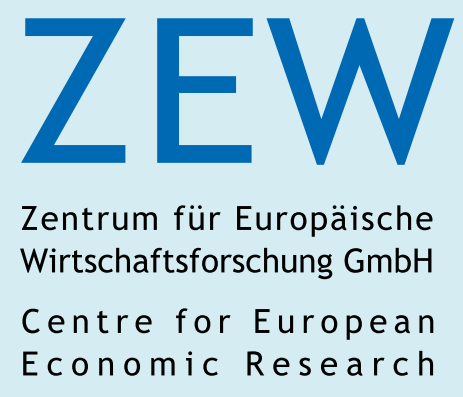




\title{
Discussion Paper No. 16-021 \\ Philanthropy in a Secular Society
}

\author{
Benjamin Bittschi, Sarah Borgloh, \\ and Berthold U. Wigger
}

Download this ZEW Discussion Paper from our ftp server:

http://ftp.zew.de/pub/zew-docs/dp/dp16021.pdf

Die Discussion Papers dienen einer möglichst schnellen Verbreitung von neueren Forschungsarbeiten des ZEW. Die Beiträge liegen in alleiniger Verantwortung der Autoren und stellen nicht notwendigerweise die Meinung des ZEW dar.

Discussion Papers are intended to make results of ZEW research promptly available to other economists in order to encourage discussion and suggestions for revisions. The authors are solely responsible for the contents which do not necessarily represent the opinion of the ZEW. 


\title{
Philanthropy in a secular society
}

\author{
Benjamin Bittschi \\ KIT Karlsruhe and ZEW Mannheim* \\ Sarah Borgloh ${ }^{\dagger}$ \\ Berthold U. Wigger \\ KIT Karlsruhe, ZEW Mannheim, and CESifo Munich ${ }^{\ddagger}$
}

February 2016

\begin{abstract}
In this study we investigate the relationship between religious and charitable giving. We test how income, the tax-price of giving and the German church tax, differently affect charitable donations of church members, individuals leaving church and nonchurch members. We find crowding in between the church tax and charitable giving for church members, but not for the church-leavers. In contrast to church members, donations of church-leavers and non-members are also highly responsive to the tax deductibility. Additionally, non-donors exhibit a significantly increased probability of leaving church compared to donors. Finally, we demonstrate that leaving church increases donations on the extensive margin but decrease giving along the intensive margin.
\end{abstract}

JEL Classification: H24, H41, Z12.

Keywords: Charitable giving, secularization, church tax, Germany, fixed-effects poisson model.

*Contact: benjamin.bittschi@kit.edu. Corresponding author.

$\dagger$ Contact: sborgloh@yahoo.de.

${ }^{\ddagger}$ Contact: berthold.wigger@kit. edu.

We are grateful to Zareh Asatryan, Lars P. Feld, Jamie Lien, Clemens Puppe, David Reinstein and Johannes Voget as well as participants in various conferences and seminars for helpful comments and suggestions. Financial support by the German Research Foundation is gratefully acknowledged. The usual disclaimer applies. 


\section{Introduction}

The influence of religion on economic behavior is a topic that has a long tradition in economic research(Iannaccone 1998; McCleary and Barro 2006). As religion is widespread and influential in the daily live of many people and given its importance for economic decision making, this is not astonishing. Then again, many countries of the so-called "Western-World" experience a strong process of societal and cultural change which becomes inter alia manifest in the process of secularization. ${ }^{1}$ On an individual level, this trend translates into a transformation of habits of daily life as expressed in the theory of modernization (Inglehart 1997). For the individual, growing self-control and growing opportunities of choice (Kaufmann 1997) form a central aspect of this process. A consequence of increasing alternatives in shaping one's life are rising opportunity costs of religious behavior due to secular competition. This in turn has been found to decrease religious participation as well as religious spending (Gruber and Hungerman 2008). However, as religious adherence has been related to different kinds of desirable social behavior (Iannaccone 1998) the question emerges whether such a trend is first and foremost a concern for the affected religions and their leaders, or whether policy makers in countries affected by an increased secularization should be equally concerned about negative spillover effects.

As huge societal trends like secularization and its consequences are notoriously elusive to grasp we narrow our research question to one realm of live where religious and secular habits cross, namely charitable giving. For instance, it is common in many religious communities that the members give a certain amount of their income to their religion. A prominent example is tithing, which can be traced backed to traditional Jewish law and which is still practiced by orthodox Jews and some Christian communities. The German church tax is a form of tithing, as it transfers a fixed share of a person's income, albeit not a tenth, towards the church. This tax is institutionally anchored in the German Income Tax system and allows us therefore to observe a taxpayer's religious affiliation in administrative tax data. Moreover, as Germany is strongly hit by the process of secularization, our setting is well suited to study the consequences of income and thus Church tax variation on church membership as well as effects of evanescent religious ties on charitable giving. Based on theoretical considerations we establish three hypotheses on the relationship between religious giving in form of the German church tax and other tax deductible donations. These hypotheses suggest that a rational acting tax unit decreases its donations when their church tax liability increases. In turn, this leads to a full or partial crowding out of other donations when the church tax increases. Consequently, the inability

\footnotetext{
${ }^{1}$ Whether secularization is taking place at all is intensely debated among sociologists of religion. For instance, Stark (1999) refutes entirely the relevance of the concept of secularization, when taking the decline of a personal belief in God as the basis of the secularization concept. However, our concept of secularization rests on the notion of an increasing deinstitutionalization and augmentation of individual choice, a fact that is also acknowledge by the critics of the secularization thesis (see Swatos and Christiano (1999)). Such a definition has been used previously in economics (Becker and Woessmann 2013) and circumvents statements about a decline in personal belief. Therefore, throughout the paper the term "non-religious" is meant to convey such a deinstitutionalization process and not as a statement about personal belief.
} 
to compensate higher church taxes by reduced donations makes non-donating church members also more likely to resign from church. Over time, the church exit should then again increase donations to the desired charity level of the tax unit. Finally, charitable giving is a field where secularization meets tax policy. That is, charity is not only a religious canon but also a publicly subsidised behavior. Insofar, the decreasing importance of religious reasons for charitable giving, especially the commitment to give fixed shares of income, can have policy consequences as it may come along with an increasing impact of tax incentives to give. Thus, we will additionally compare how religious and non-religious individuals differently react to tax incentives (expressed by the tax price of giving) for charitable giving.

In our analyses we do not find a crowding out effect of the church tax on charitable donations. Still, a clear relation between the church tax and charitable giving becomes apparent. We provide evidence that a crowding in emerges between the church tax and tax deductible donations for church members. In contrast, for individuals leaving the church the church tax exhibits no statistically significant relation to tax deductible donations.

Concerning the decision to leave the church, our results demonstrate that the probability of exiting church increases significantly with a rising church tax and for non-donors. Rising income alone, however, as some forms of the secularization hypothesis would suggest does not influence the decision to leave the church. Having left the church we observe that former members increase their donations along the extensive margin, which is however accompanied by charity reductions along the intensive margin.

Pertaining to differences in the giving behavior between religious and non-religious, we observe that the donations of church-leavers and non-church members are strongly influenced by the tax price of giving, whereas for church members this tax incentive is not relevant.

\section{Religion and charitable giving}

Many religions view prosocial behavior as an important part of leading a life agreeable to God and the central texts of the three major Western religions, Judaism, Christianity and Islam, point to the obligation of charitable giving (Eckel and Grossman 2004; Norenzayan and Shariff 2008). This obligation corresponds with the amounts of money given to religious causes. In the US religion receives approximately a third of all charitable giving, which is the largest share among all charitable causes (Giving USA 2013). In Germany, despite being much stronger secularised, still roughly a quarter of donors gave to religion in 2009, making it the fourth most supported charitable item (Infratest, TNS 2011).

As religious giving rests on a strong normative basis, it appears consequential to investigate the influence of religion on giving in general, and especially concerning its relationship to other donations. Regarding the influence of religion on charitable giving, a broad literature across all disciplines of social science exists that frequently concludes that religion, specified as affiliation, attendance, preference, denomination, beliefs or socialization, is an important de- 
terminant of giving (Bekkers and Schuyt 2008). However, the questions remains whether this result can be causally traced back to religion and whether the increased likelihood of giving is confined towards (one's own) religion or if it also spills over to secular causes. Regarding the first point, concerns have been raised that results of self-reported surveys simply reflect socially desirable behavior, i.e. that religious persons are more concerned about maintaining a prosocial reputation than the nonreligious and thus report higher levels of charitable giving (Norenzayan and Shariff 2008). While it can be seen critical whether making false statements can indeed sustainably manage self-reputation of religious people, further arguments in this direction can be put forward. From Tullock (1966) onwards economist made the argument that donors take reputational effects of giving into account. Glazer and Konrad (1996) provide a theoretical signaling explanation for charity where observable donations serve as a wealth or income signal and Harbaugh (1998a, 1998b) investigates theoretically and empirically the importance of prestige considerations for charitable giving. A stronger influence of reputational effects on religious compared to non-religious individuals might thus explain their higher giving levels. Closely related, social norms can provide an additional explanation for higher giving by the religious. Sugden (1984) introduces the principle of conditional commitment where contribution levels are determined by the (minimum) contributions in a reference group. Holländer (1990) extends this research and develops a theory of how such norms may evolve. His model suggests that individual giving is motivated by social approval and approval in turn depends on the deviation between individual donations and average donations from the peers. While these arguments can be labeled as "supplied side" driven, there may also be "demand side" reasons for differences in giving between religious and nonreligious. For instance, if fundraisers assess the religious as more generous, irrespective of the validity of this assessment, they will consequently address them more often with charitable solicitations, an effect described by Bekkers and Schuyt (2008).

Relating to spillovers from religious to secular causes, a survey by the Independent Sector (2002) revealed that religious givers (i.e. giving to religious congregations, such as churches, temples, and mosques) are more generous than nonreligious givers. Interestingly, donors who give to both religious congregations and secular organizations make higher donations to secular organizations than those who give only to secular organizations. Hence, giving to religious causes is not negatively related with giving to secular causes.

Eckel and Grossman (2004) challenge this finding as the Independent Sector's religious organization category does not differentiate religious and non-religious receivers of some charitable causes such as schools or hospitals. Using experimental data they find the greater generosity of religious givers being confined to churches and church-based institutions. Then again, other experimental papers (for a recent example see (Chlaß et al. 2015)) do find religion as an important factor for charitable giving. Surveying the experimental literature on the influence of religion on cooperation, trust and altruism, Hoffmann (2013) concludes that the influence of religion on these outcomes tends to be weak, strengthening the point that in a controlled environment with fixed levels of solicitation and no possibility for reputation management the prosocial effects of religion vanish. 
A few more recent papers can be related to our study. Hungerman (2013) investigates church exit decisions by Catholics as well as their donation behavior triggered by the sexual abuse scandal of minors by Catholic clergy revealed in 2002. His results show that this shock caused a decline of two million members of the Catholic Church and an increase in non-Catholic participation as well as non-affiliation. Concerning donations he suggests an increase of donations to non-Catholic denominations by about $\$ 2.8$ million for half the decade following the scandal. Another paper on the abuse scandal and its consequences (Bottan and Perez-Truglia 2015 ) indicates that while the scandal affected religious participation it had no influence on religious beliefs or other forms of prosocial behavior. This finding favors the evidence that an increase in charitable giving by the religious is due to social mechanisms such as solicitation and social pressure.

Finally, due to its limited prevalence papers barely address church taxes. One exception is a paper by Lyytikäinen and Santavirta (2013). The authors investigate the effect of a church tax on church membership in Finland and provide evidence that a one standard deviation increase in church tax leads to a 0.5 to 1 percentage point decline in the likelihood of church membership. Furthermore, a legislative change that made opting out easier led to a significant increase in the decline of church membership.

\section{Institutional background}

\subsection{Secularization and Religion in Germany}

The religious landscape in Germany is characterised by a division into three, approximately commensurate parts. $31.2 \%$ of the German population belong to the Roman Catholic Church, $30.8 \%$ to the Evangelical Church and $33.0 \%$ have no religious affiliation (Statistische Ämter des Bundes und der Länder 2011). Moreover, there is a relatively clear geographical division between these three groups. The south and the west are mainly catholic, while the north and the center are mainly protestant. The east, reflecting its recent history of a forced secularization by the communist regime, is mainly populated by persons without religious affiliation. Beside East-Germany, many urban areas (including the three biggest German cities Berlin, Hamburg and Munich) have a predominately unchurched population (see also figure A1 in the Appendix). As depicted in figure 1 recent years gave rise to a further decline in membership and church attendance in the Catholic and Protestant church.

To sum up, Germany has experienced a high level of secularization which even accelerated over time. This also influences funding and activities of the churches in Germany as described in the next section. 


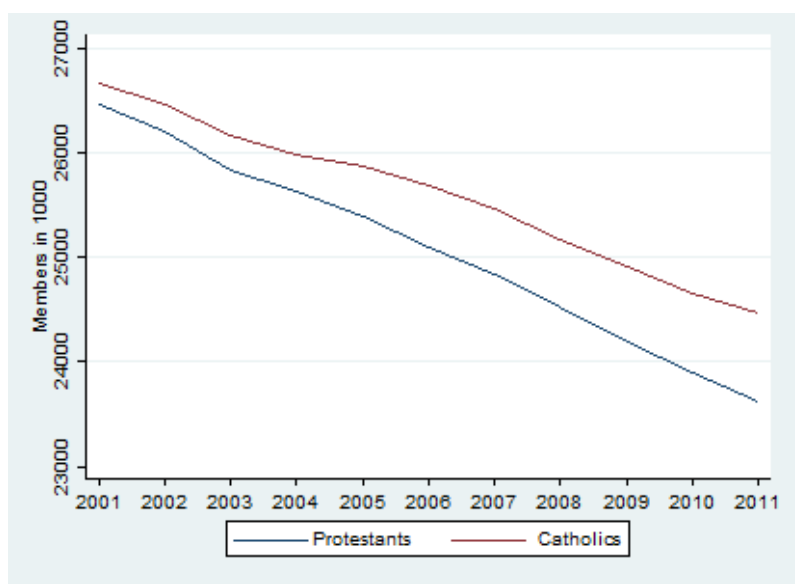

(a) Decline of churchmembers

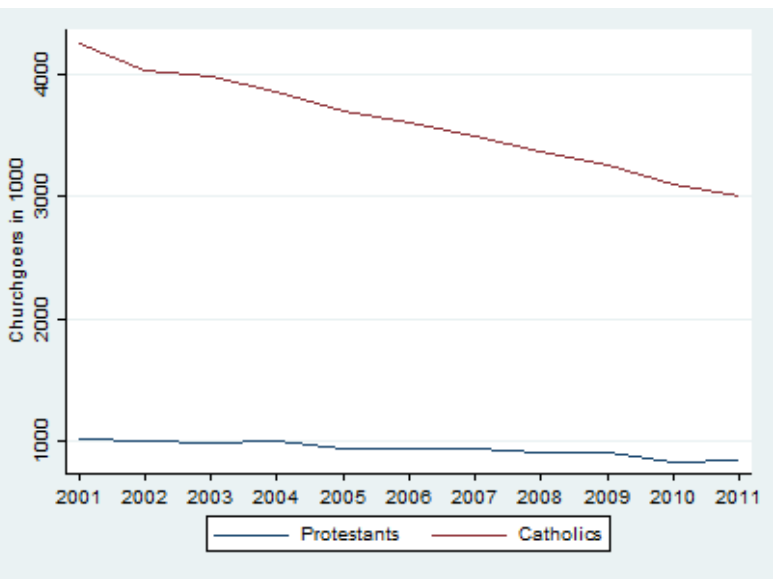

(b) Decline of churchgoers

\subsection{The German church tax}

Religious communities in Germany, which are recognised as public law corporations, are entitled to raise a church tax from their members. For an allowance the church tax is computed and collected by the public tax authorities when assessing a taxpayer's income tax and then forwarded to the respective religious community. ${ }^{2}$ In all federal states, the Catholic Church and the Protestant Church have the tax collected by the tax authorities, and in some states the Jewish Communities and some free religious communities do so. The church tax amounts to $8 \%$ in the federal states of Bavaria and Baden-Wuerttemberg and to $9 \%$ in all other federal states of the so-called fictitious income tax liability, whose computation equals the standard taxable income less child allowances and under disregard of the shareholder-relief system. ${ }^{3}$

Legally, the Church Tax Laws of the sixteen federal states, complemented and further specified by the decrees of the religious communities, provide the guidelines for the collection of the church tax. The federal structure of Germany leads to sixteen distinct church tax regulations, which differ in some aspects for determining the church tax liability. For instance, some communities limit the church tax liability to a certain share of the fictitious taxable income. In some federal states the consideration of this upper limit is guaranteed ex-officio, whereas, in the other states the taxpayer needs to send a request to the respective religious community. Furthermore, some communities demand from each member a minimum amount of church tax, mostly 3.60 Euros per year, if the fictitious income tax was greater than zero.

The church tax payments of individually assessed and jointly assessed couples with the same religious affiliation are easily calculated and fully benefit their religious community. However,

\footnotetext{
${ }^{2}$ Bavaria is the only exemption where churches collect the church tax autonomous.

${ }^{3}$ From 2001 to 2008, the German income tax law stipulated that $50 \%$ of the income from shareholdings in corporations (= "partial exempt income") would be exempt from income tax (= "shareholder-relief"). In order to compute the church tax liability, however, this exempt part of the income is added to taxable income and thus taken into account.
} 
for couples with different religious affiliations the computation of the church tax liability is more complex. More detailed information on the computation of the church tax liability and on legal church tax regulations in each of the sixteen German states can be found in the section D and tables A9 to A26 in the appendix.

Church tax payments are regarded as special expenses and can be deducted from overall income. Therefore, the tax price of church membership resembles the tax price of charitable giving and is decreasing with higher marginal tax rates. Thus, church membership is relatively cheaper for high income earners despite increasing absolute church tax payments. For members the church tax payment is obligatory and the only possibility to avoid it is to leave the community, hence, the church tax can be seen as a voluntary tax payment. While leaving the church might still give the opportunity to "free ride" on certain church services, like sending one's own children to a denominational kindergarten or attending masses, it certainly involves also costs. In fact, administrative fees of the church exit are small, amounting between $€ 5$ and $€ 60$ to be paid at a civil registry office or by a notary. However, the indirect and social consequences of the church exit can be more severe. For instance, it is not possible to have a church wedding or funeral as well as serving as a godparent for a (child) baptism after exiting the church. Additionally, the church exit would lead to a lay off when being employed at a church institution or will make it impossible to be employed at any institution whose funding body is the church. This can be a difficulty as the church is a large employer in Germany, especially in the social sector. Therefore, leaving church involves certainly costs for those people intending to leave or have left the church and can be seen as the last step in diverging from an institutional system of belief as embodied by a church.

Finally, in some respects the church tax is similar to charitable contributions. This is not only as both are income tax deductible but also as religious educational institutions and social services benefit from a certain share of the church tax revenues. Despite their similarities, the interrelation of the church tax and private charitable contributions has not been studied so far. For this reason, we establish in the next section three hypotheses on how church tax payments interact with other charitable donations and derive consequences of religious membership and prosocial behavior.

\section{Research hypotheses}

In this section we establish the research hypotheses which shape in our view the interplay between charitable and religious donations and the probability of exiting the church. We assume that households rationally decide on donations and on being a church member, liable to a church tax. This is the case, if the household derives a positive benefit from church membership. Otherwise, the household will terminate church membership and become a non-member. The voluntary decision on being a church member and, thus, paying the church tax, makes it likely that households perceive the church tax liability as a contribution to a public good, 
similar to a charitable donation. Furthermore, we assume that charitable giving is a normal good and hence, total charity increases with raising income. While non-member donations are not affected by an increase in the church tax, we assume that a church member neutralises a higher church tax liability by reducing other charitable donations. Essentially, this is the well known crowding out phenomenon as formulated in Roberts (1984) and Bergstrom et al. (1986) incorporating a church tax payment. This leads to our first hypothesis on the interplay between religious donations in the form of the church tax and all other charitable donations.

Hypothesis 1: Church members decrease charitable donations, when their church tax liability increases.

It is important to note that the more the church tax payment is perceived like other charitable donations, the stronger will be the crowding out effect. Contrary, receiving a warm glow from the church tax payment will, ceteris paribus, reduce the crowding out effect. As we distinguish in the empirical analysis church members and church leavers (persons exiting from church during the observation period) we additionally assume that the crowding out effect is less pronounced for people staying with the church.

In case of a full crowding out, church members will only suffer a utility loss from an increase in the church tax if they do not donate to charitable causes in addition to the church tax. The intuition underlying this result is simple. A church member neutralises the effect of an increase in the church tax liability by reducing donations in the same amount. The increase in the church tax liability does not affect the total amount she wants to contribute to charitable causes including the church. In contrast, a church member who does not donate, generally contributes more to a charitable cause in the form of the church tax liability than she regards to be optimal. If the church tax liability increases, she is urged to contribute an even higher amount than the one already regarded as too high. As a consequence, an increase in the church tax liability makes a non-donating church member worse off. Since a non-member is generally not affected by an increase in the church tax liability, its effect on a church member has a straightforward empirically testable implication. We formulate this implication as our second hypothesis.

Hypothesis 2. A non-donating church member is more likely to resign from church when the church tax liability increases than a donating church member.

From hypothesis 2 a straightforward extension can be derived. Given a church member has resigned from church, her income will raise by the amount of the saved church tax liability. For a desired positive public good contribution, and given the normal good character of donations, this implies that the surplus in income should also increase charitable donations. This leads to our third and final hypothesis.

Hypothesis 3. After exiting church, a church-leaver will increase charitable donations. 


\section{Data and research design}

\subsection{The Taxpayer Panel}

The Taxpayer Panel is derived from the yearly German Income Tax Statistics by the Federal Statistical Office (FSO). The unit of observation is the single tax return and not the single taxable individual. If married couples choose a joint assessment, they get the identical tax identification number and are therefore considered as one observation, so in the following the term "tax unit" will be used to label the unit of observation. To construct a panel data set, the FSO linked up the observations of the single years using individual tax identification numbers and other identifiers such as place of residence, religious affiliation, gender, and realization of different types of income. Persons that could not be linked up are typically young professionals or retirees, leading to a higher average income in the panel dimension compared to the cross-sections. In sum, the taxpayer panel contains 16.4 million tax units (Kriete-Dodds and Vorgrimler 2007).

The data on which we base our analysis is a stratified 5\% sample of the Taxpayer Panel 2001-2006. From this 5\% sample we extract two samples consisting on the one hand of church members, and on the other hand of non-church members, i.e., persons that did not belong to a church in the observation period. ${ }^{4}$ Additionally, we use a specific sub-sample of the Taxpayer Panel containing all persons exiting a religious community between 2001 and 2006. The 5\%sample comprises approximately 825,000 yearly observed tax units stratified by the federal state of residence, the type of assessment, the prevailing type of income, average overall income across all years, and the relative variation of the overall income between years. The data is anonymised by dropping exact information of the state of residence for high income earners and replacing it by an indicator of living in East or West Germany. Further, the twenty tax units with the highest income in each federal state are excluded and all dates of birth are set to January 1st of the respective year.

Besides information on a tax unit's charitable contributions, the data contains very detailed information on all tax relevant attributes of the tax units (more than 1,300 variables) which allow an accurate computation of taxable income and marginal tax rates. Details on the tax unit's religious affiliation, available for both partners in case of joint assessment, and information on the federal state of residence are necessary in determining the church tax. Moreover, the Taxpayer Panel provides information on several socio-demographic characteristics of the tax units like gender, marital status, age, and the number of children living with the taxpayer. It should be kept in mind that only individuals filing an income tax return consecutively from

\footnotetext{
${ }^{4}$ Strictly speaking, the second sample may also include members of religious communities not eligible to raise a church tax. However, as mentioned in section 3.1 the vast majority of these people are unchurched persons.
} 
2001 to 2006 are included in the data.

Using administrative tax data circumvents some of the data problems mentioned in Section 2. Relating to the reputation argument, a concern in survey data, tax deductible donations are subject to auditing by the tax authorities. Thus, purposefully reporting higher amounts of donations in order to evade taxes can result in additional tax payments, fines, and even imprisonment. Therefore, widespread misreporting of donations for reputation reasons appears unlikely in administrative tax data. ${ }^{5}$ Finally, survey data frequently misses information on wealth, whereas tax data allows a rough control for capital and real estate assets via income from these sources.

For the analysis we excluded all tax units with inconsistent socio-demographic information and dropped tax units, which are assessed separately in consecutive years, but nevertheless change their gender. Moreover, we excluded all observations from taxpayers aged below 15 and from taxpayers with restricted tax liability, i.e., taxpayers who earn income in Germany but live abroad.

\subsection{Variables}

To analyse the effects of the church tax and a church exit on charitable giving we sum the declared donations and membership-fees as dependent variable, "Giving", G. ${ }^{6}$ The variable does not reveal the various charitable causes donations go to, as this information is not tax relevant and therefore it may entail religious giving beyond the church tax. Thus, in the baseline analyses the crowding out effect between $G$ and the church tax implies an effect on all other charitable contributions or giving in general. However, donations for scientific purposes are separately reported in the tax data and we use this to test the robustness of our results. To investigate the extensive margin of charitable giving we consider a dummy variable $D$ taking on the value one if a tax unit donates in a certain year.

The dummy $E$ stands for a taxunit's church exit. In case of joint filing this dummy also assumes the value one if a single spouse is leaving church. As the Taxpayer Panel is a yearly statistic we observe the information on church exit in the subsequent year.

$C$ is the church tax liability. As the church tax liability is a function of taxable income which depends on charitable contributions we compute an exogenous measure of the church tax

\footnotetext{
${ }^{5}$ German tax authorities request for donations under $€ 200$ a bank account statement from the donor ("vereinfachte Spendenbescheinigung") and for donations above $€ 200$ an official donation receipt from the charity. This complicates tax evasion via donations as it would require a donation re-transfer from the beneficiary to the donor. For an investigation of tax evasion via misreporting charitable donations see Fack and Landais (2016). In contrast, Gillitzer and Skov (2013) demonstrate a doubling in the number of tax deductions claimed, and a 15 percent rise in the value of claims by investigating the change from self-reported charitable contributions to third party reported donations. They concluded that while charitable over-reporting is negligible, it is far more often the case that claims of charitable donations are incomplete.

${ }^{6}$ The data does not distinguish between membership-fees or charitable contributions. Membership fees paid to sports clubs or cultural activities which are of recreational nature are not tax deductible. Donations to political parties are not included because they underlie a different tax treatment.
} 
under the assumption of zero donations. Due to the anonymization process no information on the federal state of residence is available for tax units in the two highest income classes with total annual incomes greater than $€ 150,000$. Instead, we know whether these tax units live in a Western or Eastern federal state. Therefore, we calculate a hypothetical church tax amounting to the sum that would have to be paid under the regulations valid for the majority of members of a religious community in a certain year in either the Western or the Eastern federal states (see tables A25 and A26 in the appendix). If a tax unit lives in a federal state where the upper limit to the church tax does not automatically come into effect, we assume that the incomemaximizing tax unit requests the exercise of this limit. In case of a church exit during the year church tax payments are due only for the months of membership.

Income $I$ is disposable after-tax income of a tax unit. As, income in the data stems from tax law and measures several sources of income (agriculture and forestry, business enterprise, self-employment, employment, capital assets, rent and leasing, other sources) we made some adjustments to obtain a better measure of a tax unit's disposable income. We add to the sum of income from all seven sources tax-free gains, tax exempt income, the tax-free share of pension income and child benefits. Then, we subtract extraordinary expenses, alimonies as well as the income tax and the solidarity surcharge. Due to the tax deductibility of donations higher charitable contributions induce a lower taxable income. To obtain an exogenous income measure, the income tax payments and the solidarity surcharge have been recalculated under the assumption that a tax unit has not made any charitable contributions.

The tax-determined price of giving $P$ is customarily defined as $1-m$, with the marginal tax rate $m$. Hence, $P$ measures a taxunit's opportunity cost of giving in terms of foregone personal consumption. Taking the progressivity of the German income tax system into account, this implies for high income earners a lower price of giving than for low income earners. As the marginal tax rate is a function of taxable income which itself depends on the amount of charitable contributions, we ensure the exogeneity of $P$ by using the so-called "first-dollar price of giving". This means we compute $m$ as the marginal tax rate without donations, a standard procedure in the literature (Triest 1998). To obtain the marginal tax rate we apply the tax scales of the years 2001 to 2006 to taxable income plus deductible donations. The German income tax law defines categories of income which are tax exempt but effectively raise marginal tax rates. Depending on the relative magnitude of taxable income and tax exempt income, marginal tax rates equal to or larger than 1 may occur. Tax units facing such expropriating taxation are excluded from the analysis as are tax units that exhibit a combination of extra-ordinary income and tax exempt income which does not permit an unambiguous calculation of marginal tax rates. Additionally, all tax units whose donations are below the standard deduction for special expenses, i.e. all non-itemisers, are assigned a price of giving of 1 . So-called borderline itemisers, who exceed the standard deduction only as a result of the amount of donations they declare in the income tax return, are excluded from the analysis to maintain exogeneity of the price variable with regard to giving. However, as the standard deduction for non-itemisers is low in Germany ( $€ 36$ for single filers and $€ 72$ in case of joint filing) this procedure changes our 
database only slightly. ${ }^{7}$

To control for a taxunit's wealth, $W$, we include the logarithmised capital income as well as income from rent and lease.

Furthermore, we summarise several socio-demographic variables in the vector $X$. Information on gender is ambiguous in the data as it depicts the gender of the individual generating the principal income. Therefore, the gender variable is combined with the information on the filing status. Married couples are not necessarily jointly assessed, but may opt for separate assessment if this is beneficial to them. Accordingly, dummy variables for single females, single males and separately assessed married individuals are included in the analysis. Married couples serve as the reference group. To account for age effects on donations we include several age-group dummies ( 15 to 24,25 to 34,35 to 44,45 to 54,55 to 64,65 and above). Again, in case of joint assessment the identifying information is the age of the principal income earner of the tax unit. The age-group from 45 to 54 serves as reference group. We control for religious affiliation by introducing dummy variables for Catholics and Protestants. Other denominations levying a church tax and non-church members respectively serve as reference category. In addition, several dummy variables for the number of children are included. The dataset contains information on the number of tax-relevant children, i.e. children younger than 18 years and children aged 18 to 26 if they have not yet completed their educational career. Dummies are included for having one child, two children, three children, and more than three children. Tax units without any children constitute the reference group. The information on the federal state of residence is used to construct a dummy variable for all tax units living in East Germany (including Berlin).

Time dummies, $T$, are included to capture common fluctuations influencing charitable donations. During the time-period under study, giving was exceptionally high in 2002 due to a flood along the rivers Elbe and Danube. Similarly, in 2005 high levels of giving are traced back to the earthquake in the Indian Ocean and the following tsunami at the end of the year 2004. Additionally, in 2002 the Euro has been introduced as a means of payment and evidence indicates that money illusion led to an increase in charitable giving (Bittschi and Duppel 2015).

Finally, all monetary values are converted into constant 2006 Euro values using the consumer price index by the German Federal Statistical Office. An overview for all described variables for the $5 \%$ sample and the different sub-samples can be found in section 5.4.

\subsection{Empirical design}

Firstly, we will test the crowding out hypothesis derived from the theoretical model, which implies that church members' donations decrease with a raising church tax liability. To do so

\footnotetext{
${ }^{7}$ Moreover, this implicates also that the Taxpayer Panel comprises a large amount of overall donations. Although, no statistic documents the overall amount of charitable donations in Germany available surveybased projections on the amount of charitable giving in Germany (GfK Charity Scope or InfratestSpendenmonitor), are regularly below the sum of all charitable donations listed in the Taxpayer Panel. Therefore, we are confident that a large part of charitable donations is represented in our data, holding especially true for big donations from high income earners.
} 
we estimate the following equation:

$$
G_{i t}=\beta_{0}+\beta_{1} C_{i t}+\beta_{2} I_{i t}+\beta_{3} P_{i t}+\beta_{4} W_{i t}+\beta_{5} X_{i t}+T_{t}+\nu_{i}+u_{i t}
$$

In equation (4) $\beta_{1}$ reveals possible crowding out effects of donations by the church tax. However, in the estimation we face the problem that many tax units report zero donations, which is a common feature of charity data. The high amount of zeros is often used as a justification to estimate Tobit models. Yet, a consistent Tobit estimation relies heavily on the assumption of a normally distributed and homoskedastic error term, a requirement that is mostly not fulfilled with donation data. Additionally, Tobit models assume that the explanatory variables affect the donation decision equally along the extensive and the intensive margin. Further, due to the incidental parameters problem, a fixed effects estimation of the Tobit model is not feasible. As a consequence one needs to assume that the individual fixed effects, $\nu_{i}$, are uncorrelated with all explanatory variables to ensure consistent and unbiased estimates. In case of charitable donations this is a strong assumption and likely to fail. For instance, fixed levels of education could not be correlated with income and equally, fixed altruistic attitudes, of importance for a donation model, have to be uncorrelated with income and all the other control variables. Finally, in order to interpret coefficients of Tobit models as elasticities it is necessary to add an arbitrary amount (often 1, 5 or 10) to zero donations in order to take the logarithm of the dependent variable. However, the choice of the amount added is arbitrary and influences estimation results. Due to these econometric problems researchers often estimate simple log-linearised ordinary least squares (OLS) models, which allow for fixed effects and are generally more robust to violations of model assumptions. Yet, also log-linearised OLS models require arbitrary number adding to the dependent variable and furthermore, in the presence of heteroskedasticity the interpretation of log-linearised OLS models can be highly misleading, even when robust standard errors are applied (Silva and Tenreyro 2006).

The fixed effects Poisson model (FEPM) offers solutions to all the aforementioned problems. The FEPM takes the non-linearity of donations data into account and it controls for unobserved heterogeneity, a crucial step in ensuring a causal interpretation of the regression coefficients, as it does not suffer from the incidental parameters problem. Moreover, the FEPM has many desirable robustness properties for estimating the parameters in the conditional mean that make it also advantageous compared to simple OLS models. In our case, except for the conditional mean, the distribution of $G_{i t}$ given the control variables and the fixed effects is completely unrestricted and neither overdispersion nor underdispersion pose a problem in estimation. Moreover, $G_{i t}$ needs not to be Poisson distributed and there are no restrictions on the dependence between $G_{i t}$ and $G_{i r}, t \neq r$ (see Wooldridge (1999) and (Wooldridge 2010)). Further advantages of the FEPM compared to Tobit and OLS models are that the parameters can be directly interpreted as elasticities and that it is unnecessary to add arbitrary values to zero donations. Simplicity and robustness make the FEPM in our view also preferential compared to more advanced Tobit models, such as correlated random coefficient models, that try to model 
heteroskedasticity directly by making assumptions about the structural form of the fixed effect (see for instance Brown et al. (2015)).

Due to these desirable properties the FEPM has been widely used by researchers in the field of international trade faced with similar data structures of (excess) zeros in the dependent variable and the presence of heteroskedasticity in constant elasticity models (Silva and Tenreyro 2006). However, despite similarities in the data structure and thus common difficulties in econometric analyses the charity literature still has focused to a large extent on the Tobit model or simple OLS estimation. To the best of our knowledge the only exception using a FEPM with donation data is Reinstein (2011).

Subsuming all covariates into $Z_{i t}$ we can specify the mean of $G_{i t}$ conditional on $Z_{i t}$ and the fixed effect $\nu_{i}$ as:

$$
E\left(G_{i t} \mid Z_{i t}, \nu_{i}\right)=\exp \left(\beta_{0}+\beta_{1} C_{i t}+\beta_{2} I_{i t}+\beta_{3} P_{i t}+\beta_{4} W_{i t}+\beta_{5} X_{i t}+T_{t}+\nu_{i}\right)
$$

Thus, $\beta_{1}$ should now reveal an unbiased and consistent estimate of crowding out effects between the church tax and other donations. Finally, a separate identification of income and the tax price requires variation in tax rates independent of other explanatory variables (Triest 1998). To solve this identification problem our data is spanning a time period (2001-2006) that includes several changes in the tax code, as depicted in figure 2. Concerning the church tax it is important to keep in mind that the church tax is a fixed share of a fictitious income tax liability (see section 3.2 ), which prevents it to be a linear combination of taxable income. Additionally, this fact also supports a separate identification of the taxable income, the tax price and the church tax. First, certain reform measures spill over to the church tax, as components in the computation of the church tax were also exogenously changed (for instance the child care allowance and the tax exempt amount of child care). Secondly, the disregard of the shareholder relief system for the computation of the church tax further untightens the connection between the church tax, taxable income and the marginal tax rate. In an extreme case with loss carried forward from income underlying the shareholder relief system (mostly speculation losses from selling shares of capital companies) it is possible to have a negative taxable income and thus, a marginal tax rate of zero, however a (high) fictitious income and thus a (high) church tax liability. This is the case as the computation of the church tax aims to represent the economic circumstances in a certain year and thus, disregards losses carried forward. Thirdly, the treatment of income under shareholder relief also changed during the observation period as the corporate income tax in 2003 was higher (26.5\%) compared to the remaining years $(25 \%)$. This changes the value of received cash dividends and hence the tax base of the church tax, introducing further exogenous variation. Fourthly, most states apply a ceiling for church tax payments (see table A9 to table A26) and these ceilings have undergone continuous reforms during the observation period, introducing exogenous variation in church tax payments and support the identification of the church tax effects. Finally, for individuals in an inter-religious marriage the income tax reform measures directly translate into changes in the tax base of the church tax (see appendix 
D for the computation of the church tax in such a case).

Figure 2: Variation in marginal tax rates, 2001-2006

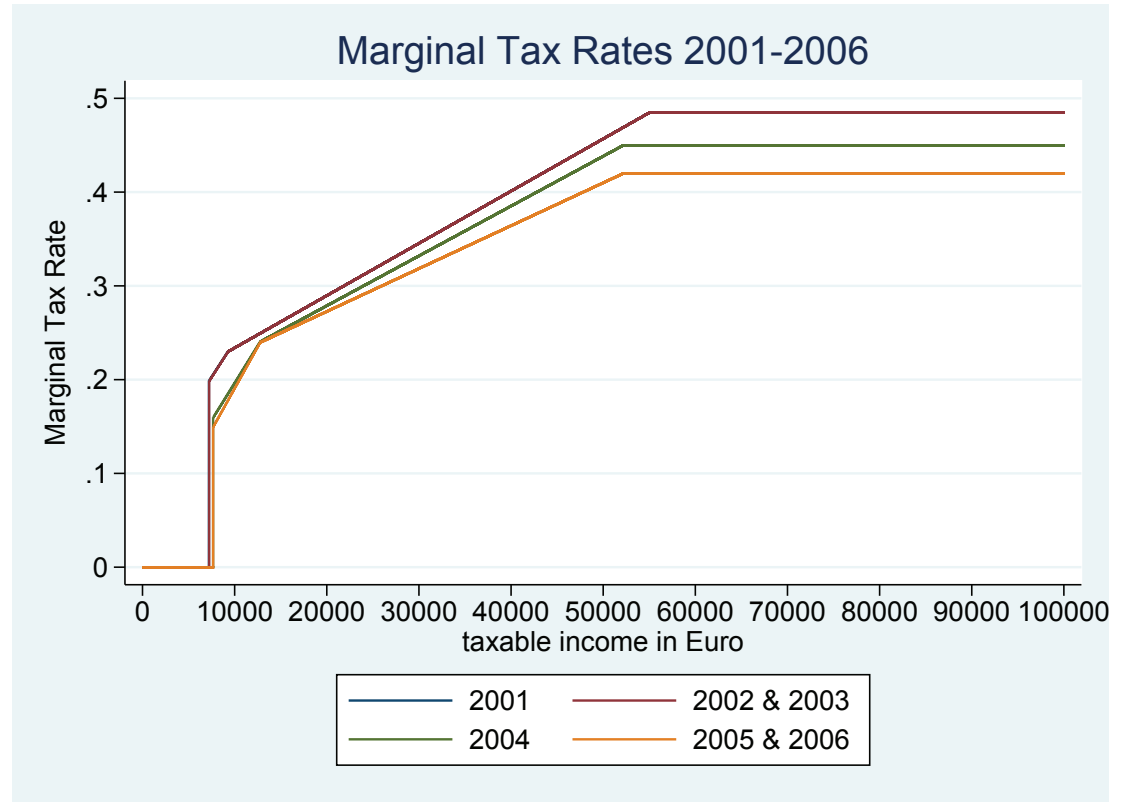

Fig.2 demonstrates changing marginal tax rates for income tax reforms taking place in 2002, 2004 and 2005.

Moreover, as mentioned in section 5.2 we calculate additionally exogenous measures of the church tax, income and the tax-price by excluding donations in the computation of these variables. Finally, by controlling for unobserved heterogeneity, we are confident that the coefficients in equation 2 represent a causal effect.

To investigate our second hypothesis whether non-donating members are more likely to resign from church when their church tax liabilities are raising we estimate the following linear probability model (LPM) of church exit:

$$
E_{i t}=\beta_{0}+\beta_{1} D_{i, t-1}+\beta_{2} C_{i, t-1}+\beta_{3} I_{i, t-1}+\beta_{4} P_{i, t-1}+\beta_{5} W_{i, t-1}+\beta_{6} X_{i, t-1}+T_{t}+\nu_{i}
$$

As we do not observe church exits during a certain year, we estimate our model using lagged values of the independent variables in order to circumvent reverse causality.

In order to test the third hypothesis we investigate whether resigned church members indeed increase their donations after exiting church. To do so, we re-estimate equation (2) and include up to four exit lags to control for dynamic adjustments in donation behavior after resigning from church, which reads:

(4) $E\left(G_{i t} \mid Z_{i t}, \nu_{i}\right)=\exp \left(\beta_{0}+\beta_{1} E_{i, t-n}+\beta_{2} I_{i t}+\beta_{3} P_{i t}+\beta_{4} W_{i t}+\beta_{5} X_{i t}+T_{t}+\nu_{i}\right)$ with $n=1,2,3,4$.

Beyond the overall effect, given by equation 4 we investigate additionally the effects at different extensive margins and along the intensive margin using linear regressions. 


\subsection{Descriptive results}

Table 1 depicts the most important variables for the $5 \%$ sample and the sample of church leavers.

Table 1: Summary statistics

\begin{tabular}{lrrrr}
\hline \multicolumn{1}{c}{ Variable } & 5\% sample & Mean (s.d.) & Sample of church leavers & Mean (s.d.) \\
\hline Dependent variables & & & & $2,640.48$ \\
Donations & 871.83 & $49,336.89$ & 93.14 & 0.43 \\
Donations Dummy & 0.45 & 0.50 & 0.24 & 0.34 \\
Exit Dummy & 0.00 & 0.00 & 0.14 & $113,217.40$ \\
Independent variables & & & & $35,137.08$ \\
Income & $81,925.68$ & $762,653.20$ & $36,735.01$ & $18,725.51$ \\
Income from Dividends & $5,007.66$ & $165,616.10$ & 594.14 & 0.18 \\
Income from Rental & $1,075.23$ & $58,018.41$ & -105.09 & $4,468.41$ \\
Price & 0.77 & 0.21 & 0.82 & 0.42 \\
Church Tax & $1,752.50$ & $17,407.91$ & 346.09 & 0.44 \\
Catholic & 0.28 & 0.45 & 0.23 & 0.03 \\
Protestant & 0.24 & 0.43 & 0.26 & 0.50 \\
Other rel. denomination & 0.00 & 0.03 & 0.00 & 0.34 \\
No rel. denomination & 0.37 & 0.48 & 0.48 & 0.43 \\
Eastern federal state & 0.21 & 0.41 & 0.13 & 0.47 \\
Single female & 0.15 & 0.36 & 0.24 & 0.10 \\
Single male & 0.22 & 0.42 & 0.34 & 0.49 \\
Married, separately assessed & 0.02 & 0.12 & 0.01 & 12.94 \\
Married couple & 0.61 & 0.49 & 0.41 & 39.32 \\
Age & 49.17 & 13.84 & & \\
\hline \hline
\end{tabular}

Source: Research Data Centres of the Federal Statistical Office and the statistical offices of the Federal States, Taxpayer Panel 2001- 2006, own calculations. All monetary values have been converted into constant 2006 Euro values.

The descriptive data overview demonstrates that tax units in the $5 \%$ sample dispose of a relatively high mean income of nearly $€ 82,000$, in contrast, church leavers only command over $€ 36,700 .^{8}$ This results from the fact that the decision to leave the church is made at younger ages in the course of starting a professional career. Hence, on average the mean age of tax units in the $5 \%$ sample is approximately 10 years older than the average church leaver age. The share of Catholics and Protestants is rather evenly distributed in both the $5 \%$ sample and the church leaver sample reaffirming figure 1 insofar as church exit affects both denominations similarly.

\footnotetext{
${ }^{8}$ The high average income in the $5 \%$ sample results from many low income households not filing an income tax return at all.
} 
Figure 3: Income adjusted donations statistics
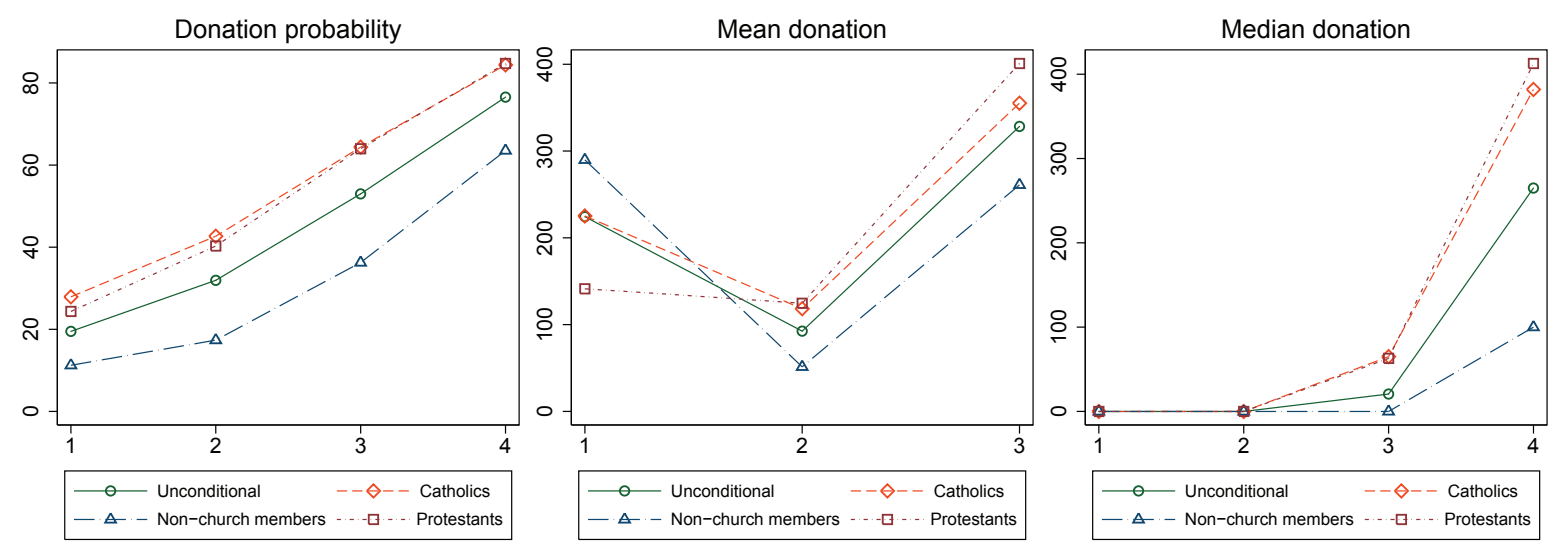

The $\mathrm{Y}$ axis of the left graph shows donation probabilities. The $\mathrm{Y}$ axes of the middle and right graph show donations in Euro. The values on the $\mathrm{X}$ axes are income quartiles. Data points represent simple means across all observations and years. Due to huge mean donations in the 4 th quartile the scale becomes uninformative, therefore the complete graph is only depicted in figure A2. Exact monetary values of each observation can also be found in table A1.

As the large deviations in average income between both groups tend to diminish the information content of the descriptive statistics, we provide in figure 3 income adjusted descriptive donation statistics. In particular, we compare church and non-church members from the $5 \%$ sample in the same income quartile. The left graph shows that, regardless of income, the donation probability, i.e. the probability of donating at all, is higher for church members than for non-church members. Moreover, between members of the two big denominations there is hardly a difference in the probability of being a donor. Furthermore, the donor-probability increases uniformly across the income quartiles for church members, whereas it exhibits an accelerating pattern across the quartiles for non-church members.

A U-shaped pattern appears for average donations among the first three income quartiles. Interestingly, the non-church members have the highest average donations in the first income quartile. In contrast to all other observations there also emerges an obvious difference in giving between Catholics and Protestants. While Catholics in the first income quartile donate approximately the same as the unconditional average, Protestants tend to give lower amounts. The picture completely changes when looking at the second income quartile. Here, the non-church members donate the lowest amount (€51), while Catholics and Protestants donate more than twice as much (Catholics, $€ 118$; Protestants $€ 125$ ). In the third income quartile charitable giving by Catholics and Protestants is still relatively close and exceeds again the amount of the first quartile. Strikingly, the donations of the non-church members in the third income quartile are still below amounts given in the first quartile. A complete turnaround of the donor ordering evolves again in the fourth quartile. Here, the non-church members donate on average again the highest amount $(€ 3,222)$, while Catholics and Protestants give considerably less (Catholics, $€ 2,612$; Protestants, $€ 2,790$ ). However, the average in the fourth income quartile is heavily affected by a few exceptionally high donations. Looking at the whole range of donations per- 
centiles it becomes evident that up to the 99th percentile church members donate always more than non-church members. This order changes at the 99th percentile with a remarkably similar average donation of $€ 23,010$ for church members and $€ 23,023$ for non-church members. Thus, the difference in the average donation of approximately $€ 580$ between church and non-church members in the 4 th income quartile results from donations in the highest percentile.

The spread of donations in the highest income quartile results from the fact that tax deductible grants to foundations, up to an amount of $€ 307,000$ per year, are included. Therefore, it is useful to take a look at median donations to complete the picture of descriptive donation statistics. In the first and second income quartile median donations are zero. In the third and fourth income quartile Catholics and Protestant make similar median donations (Catholics $€ 65$, $€ 382$; Protestants, $€ 63$, €413), while non-church members consistently give lower amounts than church-members in these two quartiles (€0 in the third and $€ 100$ in the fourth quartile). ${ }^{9}$

The descriptive statistics support the view that the religious, irrespective of income, are more generous than the non-religious. Additionally, we can draw first precautious inference that while giving by the religious seems to be income dependent, the non-religious appear to react more to tax incentives. This indication is on the one hand supported by the fact that the donation probability rises more steeply with higher income, and thus lower prices of giving, for non-church members. On the other hand, the relatively high donations of non-church members in the 1st income quartile suggest the assumption that these tax units posses higher financial possibilities for charitable giving as reflected in disposable income, and that these donors may also give in order to retain a low taxable income.

In order to see whether we can give our claims a causal interpretation we will now turn to the regression results.

\section{Regression results and discussion}

In order to review Hypothesis 1, Table 2 depicts the effects of income, the tax price of giving and the church tax on charitable donations for church members, leavers and non-members as well as additionally for the $5 \%$ sample. The first line of table 2 demonstrates the elasticity of income with respect to charitable giving. With the exception of church leavers the income elasticity is approximately 0.4 and thus relatively similar between members and non-members. That is, a $1 \%$ increase in income, raises charitable donations by $0.4 \%$. For the church leavers this figure is with $0.5 \%$ slightly higher. However, overall raising income has a similar effect on donations across all groups.

In contrast, the tax price effect of giving on donations differs significantly across the different groups. For church members the tax price apparently does not influence charitable giving. Hence, deduction possibilities for donations play no role in their giving decisions. We interpret

\footnotetext{
${ }^{9}$ Information on the donation probability and on the distribution of donations across income quartiles can be found in table A1 in the appendix. Due to data confidentiality we do not know exact values of the highest donation.
} 
this as an indicator that church members perceive charitable donations as a religious obligation and base their charity decisions on income rather than on tax incentives. Contrariwise, for the church leavers and non-members the price of giving is highly significant, price elastic and thus treasury efficient. That is, for these subgroups tax subsidised charity generates more in additional donations than it cost forgone tax revenues. More concretely, a one euro tax subsidy leads to $€ 1.05$ in donations for church leavers and $€ 1.20$ for non-members.

With regard to the church tax it becomes evident that in the $5 \%$ sample the church tax is positively related to donations, i.e., a rising church tax "crowds-in" further donations. This effect is entirely driven by the church members (column 2). More precisely, a $10 \%$ increase in the church tax increases charitable donations of church members by $0.87 \%$. For those leaving the church the effect is statistically and economically completely insignificant, and does not influence donations.

Table 2: Church tax effects on charity

\begin{tabular}{|c|c|c|c|c|}
\hline & $5 \%$ sample & $\begin{array}{c}(2) \\
\text { Members }\end{array}$ & $\begin{array}{c}(3) \\
\text { Leavers }\end{array}$ & $\begin{array}{c}(4) \\
\text { Non-members }\end{array}$ \\
\hline Income & $\begin{array}{l}0.449^{* * *} \\
(4.67)\end{array}$ & $\begin{array}{l}0.436^{* * *} \\
(3.41)\end{array}$ & $\begin{array}{l}0.523^{* * *} \\
(5.52)\end{array}$ & $\begin{array}{l}0.416^{* * *} \\
(6.24)\end{array}$ \\
\hline Tax price & $\begin{array}{c}-0.142 \\
(-0.67)\end{array}$ & $\begin{array}{c}0.194 \\
(0.65)\end{array}$ & $\begin{array}{l}-1.048^{* * *} \\
(-6.81)\end{array}$ & $\begin{array}{l}-1.209^{* * *} \\
(-4.34)\end{array}$ \\
\hline Church tax & $\begin{array}{l}0.058^{* *} \\
(2.75)\end{array}$ & $\begin{array}{l}0.087^{* * *} \\
(3.48)\end{array}$ & $\begin{array}{c}-0.001 \\
(-0.09)\end{array}$ & \\
\hline Further controls & YES & YES & YES & \\
\hline$N$ & $1,613,520$ & $1,217,570$ & $1,128,170$ & 476.535 \\
\hline
\end{tabular}

Beyond elasticities over the whole range of donations it is also interesting to investigate donor behavior at specific margins, as donations in administrative tax data show a very high variance, suggesting large heterogeneity in donation decisions. We do so by estimating equation 1 with OLS for the extensive margin, i.e., whether a tax unit gives at all (yes/no) and for donations exceeding frequently donated margins of $€ 25$, $€ 100$, and $€ 1000$. The use of such linear probability models (LPM) also provides a robustness check for our results, as LPMs are a suitable alternative for Tobit models when the dependent variable has excess zeros (see Angrist and Pischke (2009)).

Table 3 depicts the influence of income, the tax price and the church tax on donation probabilities at different margins for church members, leavers and never members. For members the probability that a donation exceeds the different margins is basically non-varying with income, that is income exerts the same influence whether the donation is just above zero or whether it is above $€ 1000$. This "constant income effect" holds also true for never-members, 
Table 3: Donations at different margins

\begin{tabular}{|c|c|c|c|}
\hline & Income & Tax Price & Church tax \\
\hline \multicolumn{4}{|l|}{ Extensive margin } \\
\hline \multirow[t]{2}{*}{ Members } & $0.023^{* * *}$ & $-0.207^{* * *}$ & 0.001 \\
\hline & $(20.04)$ & $(-45.37)$ & $(1.55)$ \\
\hline \multirow[t]{2}{*}{ Leavers } & $0.014^{* * *}$ & $-0.230^{* * *}$ & $0.001^{* * *}$ \\
\hline & $(28.45)$ & $(-79.11)$ & $(4.34)$ \\
\hline \multirow[t]{2}{*}{ Never-Members } & $0.009^{* * *}$ & $-0.274^{* * *}$ & \\
\hline & $(9.15)$ & $(-88.26)$ & \\
\hline \multicolumn{4}{|l|}{$€ 25$} \\
\hline \multirow[t]{2}{*}{ Members } & $0.022^{* * *}$ & $-0.219^{* * *}$ & -0.000 \\
\hline & $(19.92)$ & $(-47.50)$ & $(-0.32)$ \\
\hline \multirow[t]{2}{*}{ Leavers } & $0.011^{* * *}$ & $-0.231^{* * *}$ & $0.001^{* * *}$ \\
\hline & $(23.40)$ & $(-82.02)$ & $(3.22)$ \\
\hline \multirow[t]{2}{*}{ Never-Members } & $0.007^{* * *}$ & $-0.287^{* * *}$ & \\
\hline & $(7.65)$ & $(-94.16)$ & \\
\hline \multicolumn{4}{|l|}{$€ 100$} \\
\hline \multirow[t]{2}{*}{ Members } & $0.024^{* * *}$ & $-0.180^{* * *}$ & -0.001 \\
\hline & $(24.55)$ & $(-45.77)$ & $(-1.74)$ \\
\hline \multirow[t]{2}{*}{ Leavers } & $0.004^{* * *}$ & $-0.166^{* * *}$ & $-0.001^{* * *}$ \\
\hline & $(10.67)$ & $(-78.26)$ & $(-2.88)$ \\
\hline \multirow[t]{2}{*}{ Never-Members } & $0.006^{* * *}$ & $-0.280^{* * *}$ & \\
\hline & $(7.39)$ & $(-107.36)$ & \\
\hline \multicolumn{4}{|l|}{$€ 1000$} \\
\hline \multirow[t]{2}{*}{ Members } & $0.022^{* * *}$ & $0.014^{* * *}$ & $0.002^{* * *}$ \\
\hline & $(32.02)$ & $(7.55)$ & $(8.91)$ \\
\hline \multirow[t]{2}{*}{ Leavers } & $0.001^{* * *}$ & $-0.011^{* * *}$ & 0.000 \\
\hline & $(10.70)$ & $(-19.43)$ & $(0.15)$ \\
\hline \multirow[t]{2}{*}{ Never-Members } & $0.009^{* * *}$ & $-0.031^{* * *}$ & \\
\hline & $(16.62)$ & $(-30.80)$ & \\
\hline
\end{tabular}

Notes: $t$ statistics in parentheses; ${ }^{*} \mathrm{p}<0.05,{ }^{* *} \mathrm{p}<0.01,{ }^{* * *} \mathrm{p}<0.001$. Income, tax price, and, church tax are measured in log scale. Member regressions $\mathrm{N}=1,675,235$; Leaver Regression $\mathrm{N}=2,815,988$; Never-members regressions $\mathrm{N}=1,057,284$. Tables A3, A4 and A5 in the appendix contain the complete results including all control variables.

however at a magnitude that is almost zero. Conversely, for church leavers, the influence of income diminishes with rising donation margins.

Considering the effects of the tax price of giving between the different groups Table 3 demonstrates that the tax price effect in general affects leavers and non-members more strongly than church members, with the only exception of donations above $€ 100$ for leavers. This reaffirms the results from the Poisson models that leavers and non-members react stronger towards tax incentives than church members. Finally, the economic significance of the church 
tax on donation decisions is almost negligible, although (due to the large sample size) the effects are occasionally statistical significant.

A potential problem of the results described is that charitable donations of church members could be solely confined towards religious causes and thus bias the results. To check this possibility we regress equation (5) again, but use scientific donations as dependent variable. From Table 4 it becomes apparent that the regression results with the altered dependent variable are comparable to the results with overall donations as dependent variable. The income effect is still significant for all three groups, however, stronger for church members than for leavers when using scientific donations as dependent variable. The tax price effect resembles the baseline results. Although the effect is no longer price elastic for non-members, leavers and non-members still react more strongly to the tax deductibility than church members. The crowding in effect of the church tax becomes statistically insignificant, although the economic significance remains attenuated for members in the case of scientific donations. For leavers the church tax exerts no effect on scientific donations.

Table 4: Church tax effects on scientific donations

\begin{tabular}{lcccc}
\hline & $(1)$ & $(2)$ & $(3)$ & $(4)$ \\
& $5 \%$ sample & Members & Leavers & Non-Members \\
\hline Income & $0.514^{* * *}$ & $0.607^{* *}$ & $0.569^{* * *}$ & $0.441^{* * *}$ \\
& $(3.49)$ & $(3.19)$ & $(4.40)$ & $(3.97)$ \\
Tax price & -0.172 & -0.455 & $-1.061^{* * *}$ & $-0.784^{*}$ \\
\multirow{2}{*}{ Church tax } & $(-0.46)$ & $(-1.15)$ & $(-3.88)$ & $(-2.06)$ \\
\multirow{2}{*}{ Further controls } & 0.037 & 0.006 & 0.003 & \\
\hline \multirow{2}{*}{$N$} & $(1.19)$ & $(0.20)$ & $(0.25)$ & \multirow{2}{*}{ YES } \\
\hline \hline
\end{tabular}

Notes: $t$ statistics in parentheses; ${ }^{*} \mathrm{p}<0.05,{ }^{* *} \mathrm{p}<0.01,{ }^{* * *} \mathrm{p}<0.001$. Income, tax price and church tax are measured in log scale. Table A6 in the appendix contains the complete results including all control variables.

To scrutinise Hypothesis 2, Table 5 depicts the influence of donation behavior on the probability of leaving the church. As expected, we find a higher probability for non-donors to leave the church. Being a non-donor increases the probability of exiting church by 1.5 percentage points. Relating this increase to the unconditional probability of a church exit, which is $14 \%$ in the leaver sample (see table 1), it turns out that the exit probabilities of non-donors are approximately $10 \%$ higher than the exit probability of donors. We trace this result back to the fact that non-donors have no possibility to compensate a higher church tax liability by decreasing donations.

Furthermore, income and the church tax have a statistically significant effect on church exit. However, given the level-log specifications of the church tax liability and income in equation (6) the effects displayed in Table 5 are small. A $10 \%$ increase in the church tax liability increases 
the exit probability only by approximately 0.3 percentage points. An increase in income of $10 \%$ reduces the exit probability by roughly the same magnitude. Related to the unconditional average this is an increase (church tax), respectively a decrease (income), in the exit probability of approximately $2 \%$.

To test whether the church tax influences the exit probabilities of donors and non-donors differently we interact the church tax payment with the donor status. Column 2 of table 5 demonstrates that the influence of the church tax on the exit probability is only slightly different between donors and non-donors. Interestingly, the church tax slope for non-donors is even 0.007 lower compared to the church tax slope of donors. To interpret the non-donor effect for the interacted regression we center the church tax variable at the mean and median. At the mean (median) of the church tax payment the effect of being a non-donor on the probability of leaving church is 2 (1.2) percentage points higher compared to donors. Related to the unconditional average this is an increase of approximately $14 \%(9 \%)$.

Table 5: Non-donor effect on church exit

\begin{tabular}{|c|c|c|c|c|}
\hline & (1) & $(2)$ & $(3)$ & (4) \\
\hline Non-donor & $\begin{array}{l}0.015^{* * *} \\
(11.59)\end{array}$ & $\begin{array}{l}0.050^{* * *} \\
(17.54)\end{array}$ & $\begin{array}{l}0.020^{* * *} \\
(14.77)\end{array}$ & $\begin{array}{l}0.012^{* * *} \\
(9.07)\end{array}$ \\
\hline Income & $\begin{array}{c}-0.034^{* * *} \\
(-29.89)\end{array}$ & $\begin{array}{l}-0.033^{* * *} \\
(-29.09)\end{array}$ & $\begin{array}{l}-0.033^{* * *} \\
(-29.09)\end{array}$ & $\begin{array}{l}-0.033^{* * *} \\
(-29.09)\end{array}$ \\
\hline Tax price & $\begin{array}{l}0.229^{* * *} \\
(55.72)\end{array}$ & $\begin{array}{l}0.228^{* * *} \\
(55.58)\end{array}$ & $\begin{array}{l}0.228^{* * *} \\
(55.58)\end{array}$ & $\begin{array}{l}0.228^{* * *} \\
(55.58)\end{array}$ \\
\hline Church tax & $\begin{array}{l}0.033^{* * *} \\
(85.49)\end{array}$ & $\begin{array}{l}0.039^{* * *} \\
(68.07)\end{array}$ & $\begin{array}{l}0.039^{* * *} \\
(68.07)\end{array}$ & $\begin{array}{l}0.039^{* * *} \\
(68.07)\end{array}$ \\
\hline Non-donor\#Church tax & & $\begin{array}{l}-0.007^{* * *} \\
(-13.73)\end{array}$ & & \\
\hline Non-donor\#Church tax (mean) & & & $\begin{array}{l}-0.007^{* * *} \\
(-13.73)\end{array}$ & \\
\hline Non-donor\#Church tax (median) & & & & $\begin{array}{l}-0.007^{\text {*** }} \\
(-13.73)\end{array}$ \\
\hline$N$ & $2,466,328$ & $2,466,328$ & $2,466,328$ & $2,466,328$ \\
\hline
\end{tabular}

Notes: $t$ statistics in parentheses; ${ }^{*} \mathrm{p}<0.05,{ }^{* *} \mathrm{p}<0.01,{ }^{* * *} \mathrm{p}<0.001$. Income, tax price and church tax are measured in log scale. All control variables are measured at $\mathrm{t}-1$. Table A7 in the appendix contains the complete results including all control variables.

Finally, Table 6 demonstrates that we can corroborate Hypothesis 3 only partly. Lagged values of the church exit are accompanied by an increase in the giving probability along lower extensive donation margins ( $€ 0 € 25, € 100$ ). Additionally, the more time passes since church exit the more the donation probability increases. Concretely, four years after the church exit a former church member has a 6 percentage points higher probability of being a donor, compared to the exit year. In contrast, the church exit decreases slightly the probability for a donation above the highest margin $(€ 1,000)$. Elapsed time since exit does not have a statistically signif- 
icant influence on that margin. Additionally, investigating the overall elasticity via the FEPM exhibits no significant results for the different exit dummies. Investigating the intensive margin, i.e., the effect of the church exit on positive donations, reveals that the church exit does not increase charitable giving as expected but leads to a decrease. As donations are logarithmic in column (6) of Table 6, church exit reduces charitable donations by by $2.3 \%$ (2.8\%) in the first (second) year after church exit. Hence, in sum resigning from church shows mixed spillover effects on the general willingness to donate. It leads to an increased donation probability along the extensive margins and to reduced donations along the intensive margin. 


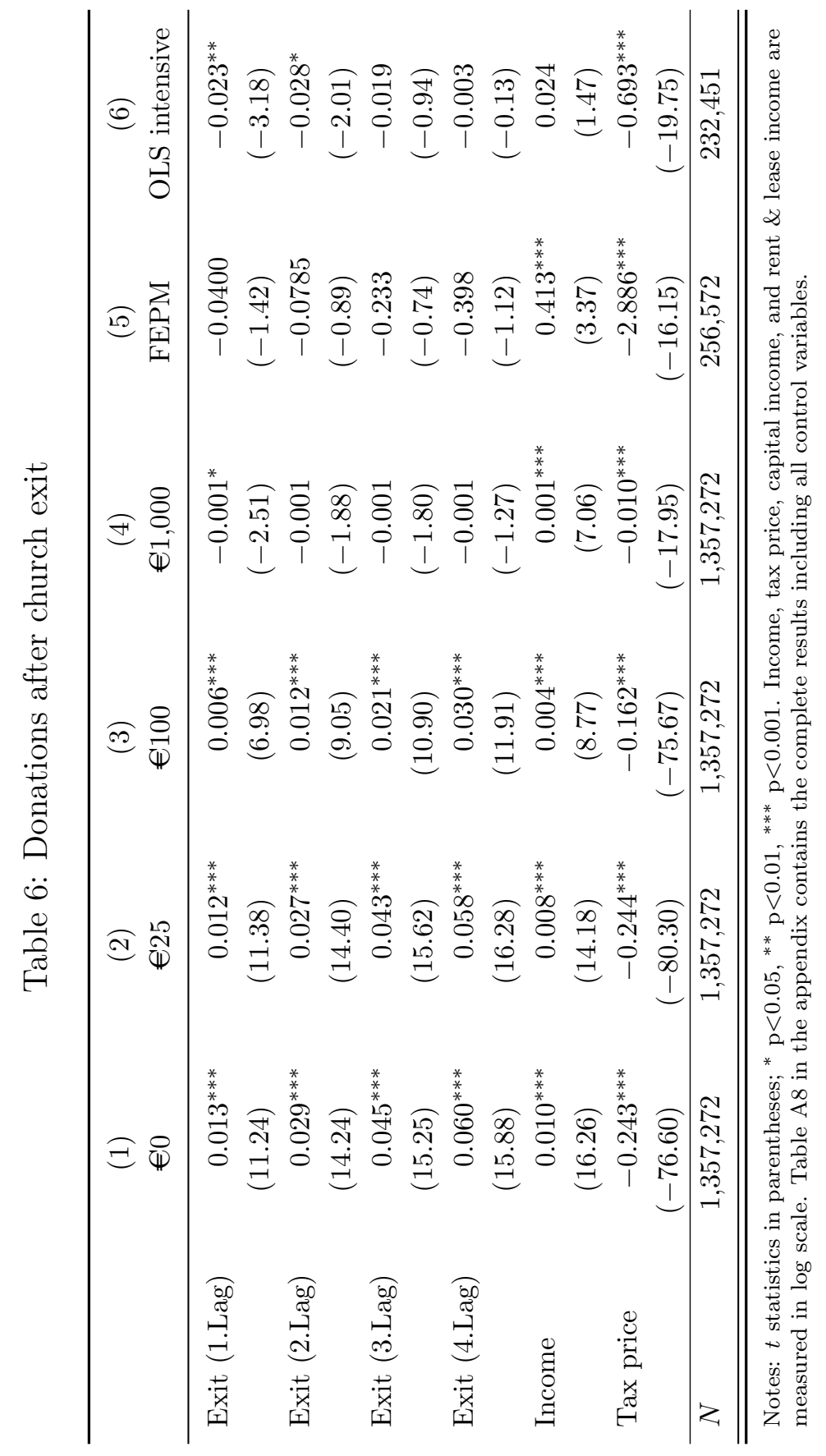




\section{Conclusion}

We have investigated the between between religious and charitable giving. We find that religious giving, indicated by the German church tax, has a moderate and significant positive influence on charitable giving for church members. This does not hold for individuals leaving the church during the observation period. For this group the church tax has no influence on their donation behavior.

Moreover, we find that non-donors are more likely to leave church. We trace this result back to the fact that non-donors have no possibility to compensate a higher church tax liability by decreasing their donations and hence, react more often by quitting church membership. A further factor shaping the exit probability is the church tax, as a rising church tax comes along with increased exit probabilities.

After resigning from church the former church members increase their donations along the extensive margin but also decrease donations along the intensive margin. Examining differences between church members, leavers, and non-members of the church, we demonstrate that deduction possibilities are not the driving force for donations for members, but play an important role in donation decisions of the two latter groups. We interpret this as an indicator that church members perceive charitable donations as a religious obligation and thus base their charity decisions only on income and not on tax incentives.

Our results suggest that a more secular society has a twofold impact on the level of charitable giving. It may lead to diminished donations by a declining crowding in effect of religious giving on other charitable donations. Furthermore, resigning from church leads to reductions in the amount of charitable donations. In contrast, church exit is accompanied by a positive influence on donation probabilities for lower extensive margins. Based on our data, the yearly loss in church tax revenue due to people resigning from church is $€ 46.9$ million. Given that a certain share of the church tax is spend to some extent for everyone's benefit, via social, health or educational services, and as the exiguous extensive margin increase is unlikely to offset church tax losses, secularization may lead over time to a reduction in the private provision of public goods. If policy makers would assess such a development as problematic, a potential solution could be the introduction of a tax similar to the Italian "eight per thousand" tax. This tax is obligatory, but the taxpayer can choose whether his tax payments benefit a certain church or other social, scientific or cultural purposes and thus could potentially avoid negative effects of secularization on charitable donations. 


\section{References}

Angrist, J. and J. Pischke (2009). Mostly Harmless Econometrics: An Empiricist's Companion. Princeton University Press.

Becker, S. O. and L. Woessmann (2013). Not the opium of the people: Income and secularization in a panel of prussian counties. The American Economic Review 103(3), 539-544.

Bekkers, R. and T. Schuyt (2008). And who is your neighbor? Explaining denominational differences in charitable giving and volunteering in the Netherlands. Review of Religious Research, 74-96.

Bergstrom, T., L. Blume, and H. Varian (1986). On the private provision of public goods. Journal of Public Economics 29(1), 25 - 49.

Bittschi, B. and S. Duppel (2015). Did the introduction of the euro lead to money illusion? Empirical evidence from Germany. ZEW Discussion Papers 15-058.

Bottan, N. L. and R. Perez-Truglia (2015). Losing my religion: The effects of religious scandals on religious participation and charitable giving. Journal of Public Economics 129, 106 119.

Brown, S., W. H. Greene, M. N. Harris, and K. Taylor (2015). An inverse hyperbolic sine heteroskedastic latent class panel tobit model: An application to modelling charitable donations. Economic Modelling 50, 228 - 236.

Chlaß, N., L. Gangadharan, and K. Jones (2015). Charitable Giving and Intermediation. Monash Economics Working Papers 18-15.

Eckel, C. C. and P. J. Grossman (2004). Giving to secular causes by the religious and nonreligious: An experimental test of the responsiveness of giving to subsidies. Nonprofit and Voluntary Sector Quarterly 33(2), 271-289.

Fack, G. and C. Landais (2016). The effect of tax enforcement on tax elasticities: Evidence from charitable contributions in france. Journal of Public Economics 133, 23 - 40.

Gillitzer, C. and P. E. Skov (2013). Evidence on Unclaimed Charitable Contributions from the Introduction of Third-Party Information Reporting in Denmark. EPRU Working Paper Series 2013-04, Economic Policy Research Unit (EPRU), University of Copenhagen. Department of Economics.

Giving USA (2013). The annual report on philanthropy for the year 2012.

Glazer, A. and K. A. Konrad (1996). A signaling explanation for charity. The American Economic Review, 1019-1028.

Gruber, J. and D. M. Hungerman (2008). The church versus the mall: What happens when religion faces increased secular competition? The Quarterly Journal of Economics 123(2), 831-862. 
Harbaugh, W. T. (1998a). The prestige motive for making charitable transfers. American Economic Review, 277-282.

Harbaugh, W. T. (1998b). What do donations buy?: A model of philanthropy based on prestige and warm glow. Journal of Public Economics 67(2), 269-284.

Hoffmann, R. (2013). The experimental economics of religion. Journal of Economic Surveys $27(5), 813-845$.

Holländer, H. (1990). A social exchange approach to voluntary cooperation. The American Economic Review, 1157-1167.

Hungerman, D. M. (2013). Substitution and stigma: Evidence on religious markets from the catholic sex abuse scandal. American Economic Journal: Economic Policy 5(3), 227-253.

Iannaccone, L. R. (1998). Introduction to the economics of religion. Journal of Economic Literature 36(3), 1465-1495.

Independent Sector (2002). Faith and philanthropy: The connection between charitable behavior and giving to religion. Washington, DC.

Infratest, TNS (2011). Deutscher Spendenmonitor 2011.

Inglehart, R. (1997). Modernization and Postmodernization: Cultural, Economic and Political Change in 43 Societies. Princeton University Press.

Kaufmann, F.-X. (1997). Religion and modernization in europe. Journal of Institutional and Theoretical Economics (JITE) 153(1), 80-96.

Kriete-Dodds, S. and D. Vorgrimler (2007). Das Taxpayer-Panel der jährlichen Einkommenssteuerstatistik. Wirtschaft und Statistik 1, 77-85.

Lyytikäinen, T. and T. Santavirta (2013). The effect of church tax on church membership. Journal of Population Economics 26(3), 1175-1193.

McCleary, R. M. and R. J. Barro (2006). Religion and economy. Journal of Economic Perspectives $20(2), 49-72$.

Norenzayan, A. and A. F. Shariff (2008). The origin and evolution of religious prosociality. Science 322(5898), 58-62.

Reinstein, D. A. (2011). Does one charitable contribution come at the expense of another? The BE Journal of Economic Analysis 8 Policy 11(1).

Roberts, R. D. (1984). A positive model of private charity and public transfers. Journal of Political Economy 92(1), 136-148.

Silva, J. S. and S. Tenreyro (2006). The log of gravity. The Review of Economics and statistics 88(4), 641-658.

Stark, R. (1999). Secularization, RIP. Sociology of Religion 60(3), 249-273.

Statistische Ämter des Bundes und der Länder (2011). Zensus. https://www.zensus2011. de/EN/Home/home_node.html. 
Sugden, R. (1984). Reciprocity: The supply of public goods through voluntary contributions. The Economic Journal 94(376), 772-787.

Swatos, W. H. and K. J. Christiano (1999). Introduction - secularization theory: The course of a concept. Sociology of Religion 60(3), 209-228.

Triest, R. K. (1998). Econometric issues in estimating the behavioral response to taxation: a nontechnical introduction. National Tax Journal, 761-772.

Tullock, G. (1966). Information without profit. Papers on Non-Market Decision Making 1, $141-159$.

Wooldridge, J. M. (1999). Distribution-free estimation of some nonlinear panel data models. Journal of Econometrics 90(1), 77-97.

Wooldridge, J. M. (2010). Econometric analysis of cross section and panel data. MIT press. 


\section{A Figures}

Figure A1: Division of religious communities in Germany

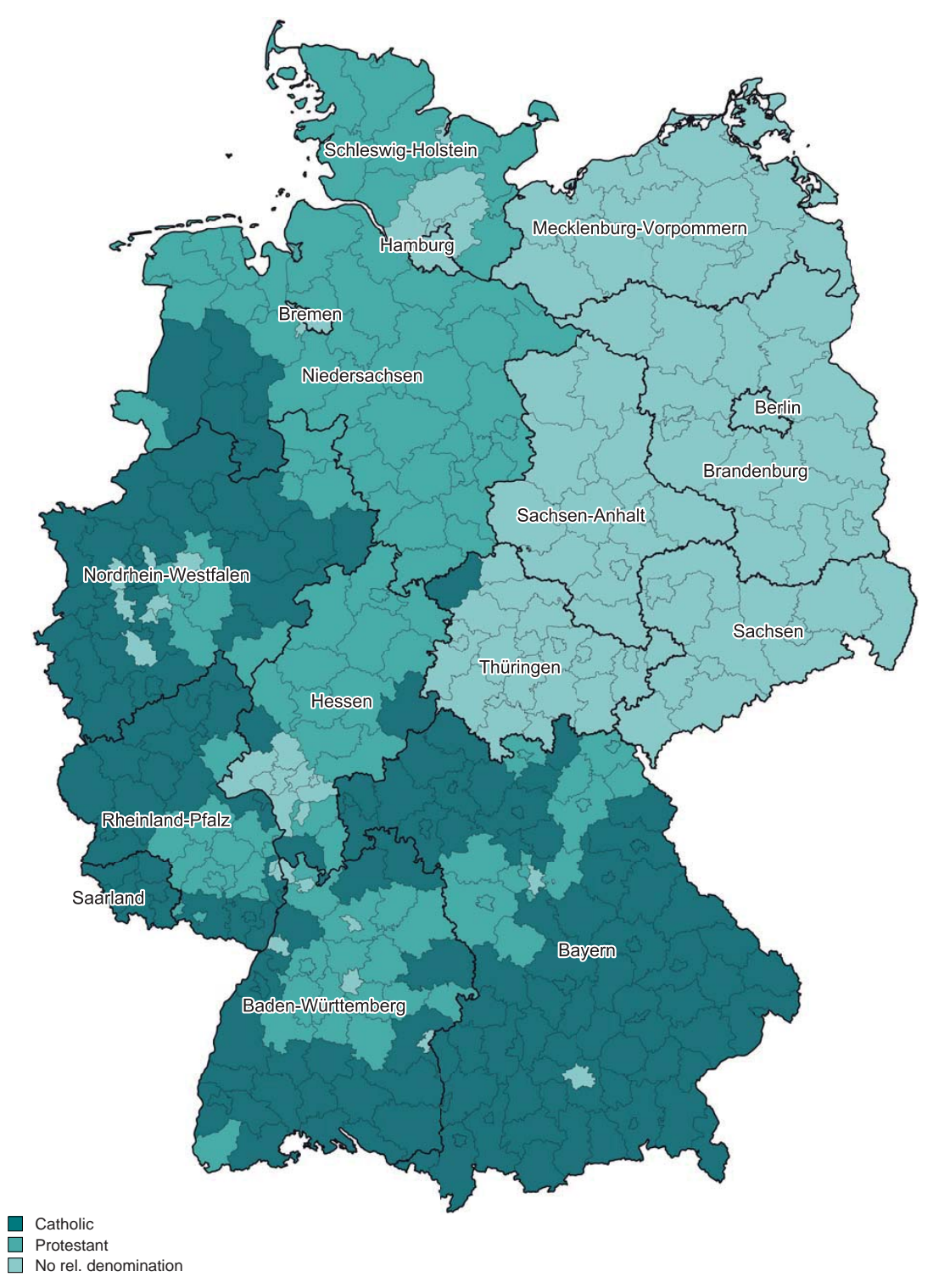

Source: Federal Statistical Office 
Figure A2: Mean donations across all quartiles

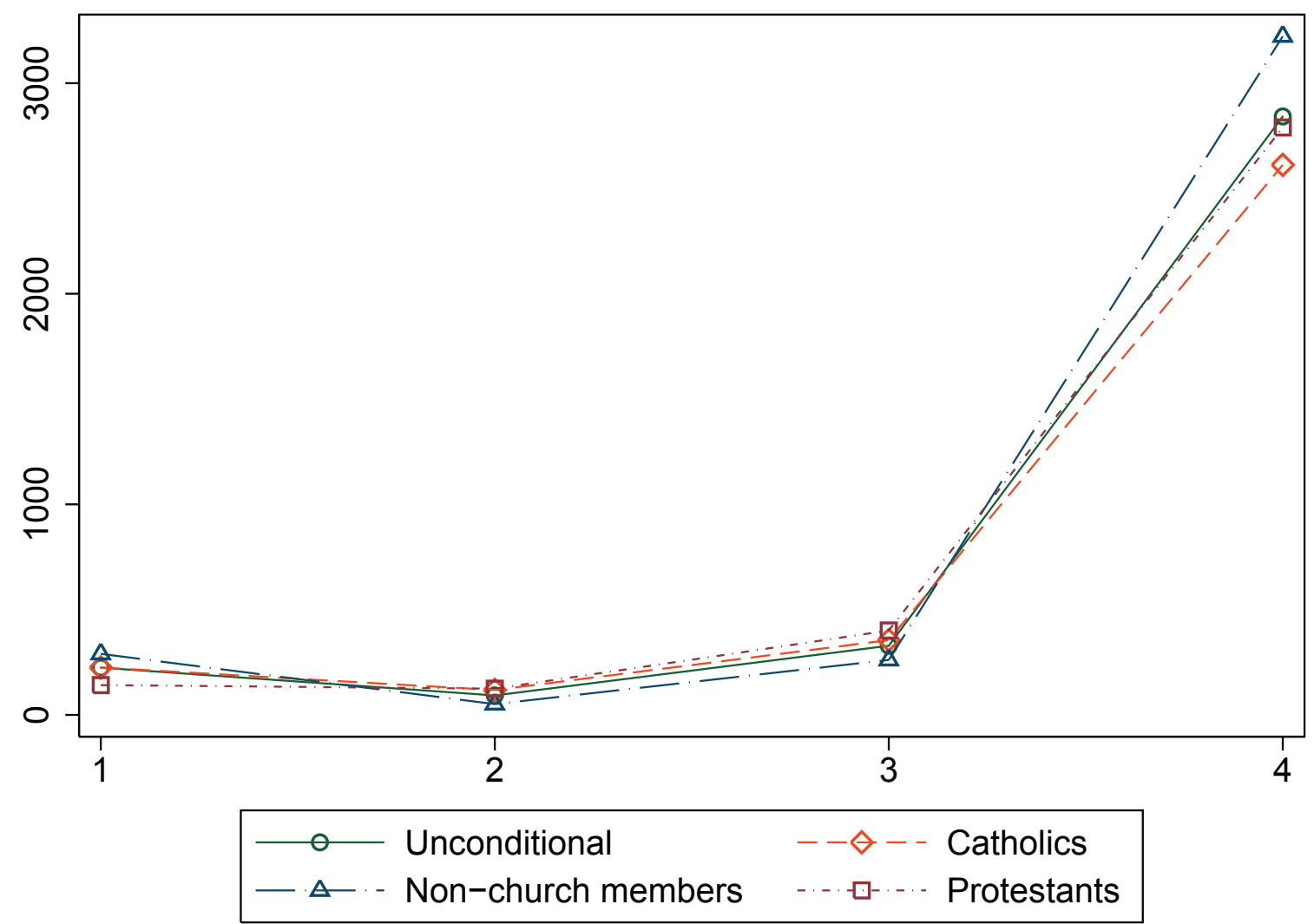

The $\mathrm{Y}$ axis of the left graph shows donation probabilities. The $\mathrm{Y}$ axes of the middle and right graph show donations in Euro. The values on the $\mathrm{X}$ axes are income quartiles. Data points represent simple means across all observations and years. Exact monetary values of each observation can also be found in table A1. 


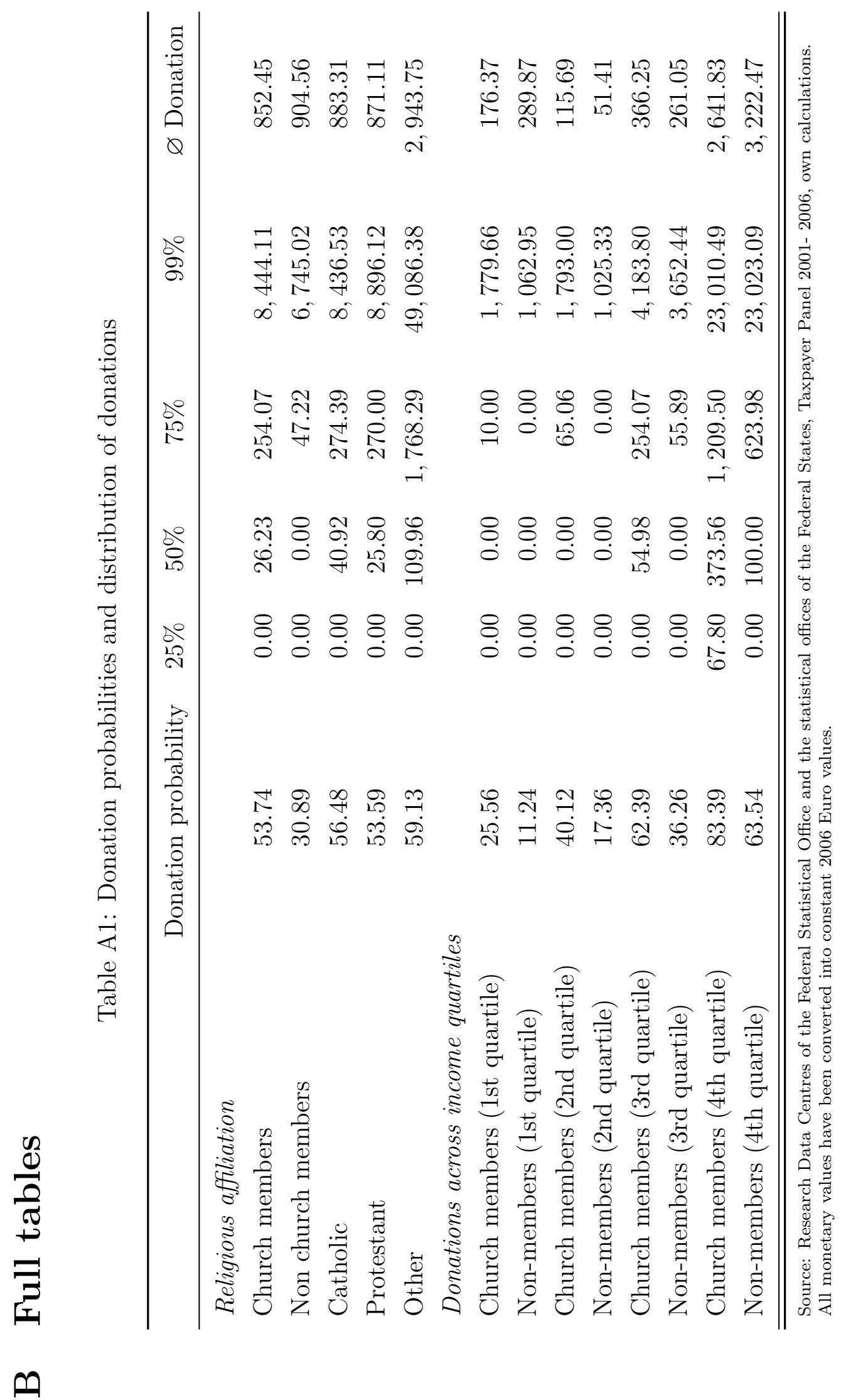


Table A2: Church tax effects on charity - full table

\begin{tabular}{|c|c|c|c|c|}
\hline & $\begin{array}{c}(1) \\
5 \% \text { sample }\end{array}$ & $\begin{array}{c}(2) \\
\text { Members }\end{array}$ & $\begin{array}{c}(3) \\
\text { Leavers }\end{array}$ & $\begin{array}{c}(4) \\
\text { Non-members }\end{array}$ \\
\hline Income & $\begin{array}{l}0.449^{* * *} \\
(4.67)\end{array}$ & $\begin{array}{l}0.436^{* * *} \\
(3.41)\end{array}$ & $\begin{array}{l}0.523^{* * *} \\
(5.52)\end{array}$ & $\begin{array}{l}0.416^{* * *} \\
(6.24)\end{array}$ \\
\hline Tax price & $\begin{array}{l}-0.142 \\
(-0.67)\end{array}$ & $\begin{array}{l}0.194 \\
(0.65)\end{array}$ & $\begin{array}{l}-1.048^{* * *} \\
(-6.81)\end{array}$ & $\begin{array}{l}-1.209^{* * *} \\
(-4.34)\end{array}$ \\
\hline Church tax & $\begin{array}{l}0.058^{* *} \\
(2.75)\end{array}$ & $\begin{array}{l}0.087^{* * *} \\
(3.48)\end{array}$ & $\begin{array}{l}-0.001 \\
(-0.09)\end{array}$ & \\
\hline Capital income & $\begin{array}{l}0.018^{* * *} \\
(5.05)\end{array}$ & $\begin{array}{l}0.020^{* * *} \\
(4.54)\end{array}$ & $\begin{array}{l}0.018^{* *} \\
(2.77)\end{array}$ & $\begin{array}{c}0.004 \\
(0.52)\end{array}$ \\
\hline Rent \& lease income & $\begin{array}{c}0.004 \\
(0.35)\end{array}$ & $\begin{array}{r}0.010 \\
(0.69)\end{array}$ & $\begin{array}{r}0.012 \\
(1.05)\end{array}$ & $\begin{array}{r}0.010 \\
(0.51)\end{array}$ \\
\hline East Germany & $\begin{array}{l}-0.002 \\
(-0.02)\end{array}$ & $\begin{array}{l}-0.056 \\
(-0.42)\end{array}$ & $\begin{array}{l}-0.010 \\
(-0.12)\end{array}$ & $\begin{array}{l}-0.075 \\
(-0.51)\end{array}$ \\
\hline \multicolumn{5}{|c|}{ Assessment type - Reference category: Married, joint assessment } \\
\hline Single female & $\begin{array}{l}-0.219 \\
(-1.15)\end{array}$ & $\begin{array}{l}-0.401^{* *} \\
(-2.75)\end{array}$ & $\begin{array}{l}-0.320^{* * *} \\
(-4.38)\end{array}$ & $\begin{array}{l}-0.095 \\
(-0.70)\end{array}$ \\
\hline Single male & $\begin{array}{l}-0.145 \\
(-1.13)\end{array}$ & $\begin{array}{l}-0.084 \\
(-0.66)\end{array}$ & $\begin{array}{l}-0.228^{* * *} \\
(-3.84)\end{array}$ & $\begin{array}{c}0.288 \\
(1.33)\end{array}$ \\
\hline Married separate & $\begin{array}{l}-0.051 \\
(-0.34)\end{array}$ & $\begin{array}{l}-0.222 \\
(-1.74)\end{array}$ & $\begin{array}{l}-0.193^{* *} \\
(-2.85)\end{array}$ & $\begin{array}{l}-0.546^{*} \\
(-2.36)\end{array}$ \\
\hline Age groups - Reference cat & $y: 45-54$ & & & \\
\hline under 24 years & $\begin{array}{l}0.733^{* * *} \\
(3.68)\end{array}$ & $\begin{array}{l}0.595^{* *} \\
(2.65)\end{array}$ & $\begin{array}{l}-0.004 \\
(-0.03)\end{array}$ & $\begin{array}{l}-0.541 \\
(-1.28)\end{array}$ \\
\hline $25-34$ & $\begin{array}{l}-0.080 \\
(-0.66)\end{array}$ & $\begin{array}{l}-0.188 \\
(-1.42)\end{array}$ & $\begin{array}{l}-0.070 \\
(-1.01)\end{array}$ & $\begin{array}{l}-0.148 \\
(-0.59)\end{array}$ \\
\hline $35-44$ & $\begin{array}{c}0.005 \\
(0.07)\end{array}$ & $\begin{array}{l}-0.054 \\
(-0.66)\end{array}$ & $\begin{array}{c}0.004 \\
(0.11)\end{array}$ & $\begin{array}{r}0.026 \\
(0.24)\end{array}$ \\
\hline $55-64$ & $\begin{array}{l}-0.071 \\
(-0.51)\end{array}$ & $\begin{array}{l}-0.032 \\
(-0.19)\end{array}$ & $\begin{array}{c}0.028 \\
(0.63)\end{array}$ & $\begin{array}{c}0.045 \\
(0.40)\end{array}$ \\
\hline more than 65 years & $\begin{array}{c}0.208 \\
(1.14)\end{array}$ & $\begin{array}{c}0.166 \\
(0.89)\end{array}$ & $\begin{array}{c}0.025 \\
(0.31)\end{array}$ & $\begin{array}{l}0.805^{* *} \\
(2.68)\end{array}$ \\
\hline \multicolumn{5}{|c|}{ Religious affiliation - Reference category: Other denominations and non-church members } \\
\hline Catholic & $\begin{array}{l}-0.223 \\
(-1.11)\end{array}$ & $\begin{array}{c}0.253 \\
(1.94)\end{array}$ & $\begin{array}{l}-0.066 \\
(-1.63)\end{array}$ & \\
\hline Protestant & $\begin{array}{l}-0.300 \\
(-1.27)\end{array}$ & $\begin{array}{c}0.034 \\
(0.13)\end{array}$ & $\begin{array}{l}-0.105 \\
(-1.96)\end{array}$ & \\
\hline \multicolumn{5}{|c|}{ Children - Reference category: no children } \\
\hline One child & $\begin{array}{c}0.083 \\
(1.66)\end{array}$ & $\begin{array}{c}0.084 \\
(1.59)\end{array}$ & $\begin{array}{l}-0.037 \\
(-1.34)\end{array}$ & $\begin{array}{l}-0.016 \\
(-0.10)\end{array}$ \\
\hline Two children & $\begin{array}{l}0.143^{*} \\
(2.07)\end{array}$ & $\begin{array}{l}0.184^{* *} \\
(2.61)\end{array}$ & $\begin{array}{c}0.009 \\
(0.21)\end{array}$ & $\begin{array}{r}0.137 \\
(0.93)\end{array}$ \\
\hline Three children & $\begin{array}{c}0.059 \\
(0.71)\end{array}$ & $\begin{array}{c}0.074 \\
(0.86)\end{array}$ & $\begin{array}{c}0.113 \\
(1.59)\end{array}$ & $\begin{array}{c}0.052 \\
(0.31)\end{array}$ \\
\hline More than three children & $\begin{array}{r}0.239 \\
(1.84)\end{array}$ & $\begin{array}{r}0.153 \\
(1.60)\end{array}$ & $\begin{array}{c}0.104 \\
(1.31)\end{array}$ & $\begin{array}{r}0.460 \\
(1.43)\end{array}$ \\
\hline Time dummies: Base year & & & & \\
\hline 2002 & $\begin{array}{l}0.191^{* * *} \\
(3.44)\end{array}$ & $\begin{array}{c}0.088 \\
(1.54)\end{array}$ & $\begin{array}{l}0.128^{* * *} \\
(5.23)\end{array}$ & $\begin{array}{l}0.272^{*} \\
(2.37)\end{array}$ \\
\hline 2003 & $\begin{array}{l}0.231^{* * *} \\
(4.04)\end{array}$ & $\begin{array}{l}0.199^{* *} \\
(2.95)\end{array}$ & $\begin{array}{c}0.079^{*} \\
(2.48)\end{array}$ & $\begin{array}{c}-0.043 \\
(-0.31)\end{array}$ \\
\hline 2004 & $\begin{array}{l}0.215^{* *} \\
(2.84)\end{array}$ & $\begin{array}{c}0.079 \\
(1.31)\end{array}$ & $\begin{array}{l}0.201^{* * *} \\
(4.13)\end{array}$ & $\begin{array}{c}0.125 \\
(0.64)\end{array}$ \\
\hline 2005 & $\begin{array}{l}0.337^{* * *} \\
(5.30)\end{array}$ & $\begin{array}{l}0.205^{* *} \\
(2.84)\end{array}$ & $\begin{array}{l}0.338^{* * *} \\
(5.04)\end{array}$ & $\begin{array}{l}0.356^{* *} \\
(2.67)\end{array}$ \\
\hline 2006 & $\begin{array}{l}0.319^{* * *} \\
(4.32)\end{array}$ & $\begin{array}{l}0.162^{*} \\
(2.24)\end{array}$ & $\begin{array}{l}0.215^{* *} \\
(3.15)\end{array}$ & $\begin{array}{l}0.415^{*} \\
(2.10) \\
\end{array}$ \\
\hline$N$ & $1,613,520$ & $1,217,570$ & $1,128,170$ & 476,535 \\
\hline
\end{tabular}

Notes: $t$ statistics in parentheses; ${ }^{*} \mathrm{p}<0.05,{ }^{* *} \mathrm{p}<0.01,{ }^{* * *} \mathrm{p}<0.001$. Income, tax price, church tax, capital income, and rent \& lease income are measured in log scale. 
Table A3: Donations at different margins - full table, members

\begin{tabular}{|c|c|c|c|c|}
\hline & $\begin{array}{c}(1) \\
\text { Extensive margin }\end{array}$ & $\begin{array}{l}(2) \\
€ 25\end{array}$ & $\begin{array}{rl} & (3) \\
€ & 100\end{array}$ & $\begin{array}{c}(4) \\
€ 1,000\end{array}$ \\
\hline Income & $\begin{array}{l}0.023^{* * *} \\
(20.04)\end{array}$ & $\begin{array}{l}0.022^{* * *} \\
(19.92)\end{array}$ & $\begin{array}{l}0.024^{* * *} \\
(24.55)\end{array}$ & $\begin{array}{l}0.022^{* * *} \\
(32.02)\end{array}$ \\
\hline Tax price & $\begin{array}{l}-0.207^{* * *} \\
(-45.37)\end{array}$ & $\begin{array}{l}-0.219^{* * *} \\
(-47.50)\end{array}$ & $\begin{array}{l}-0.180^{* * *} \\
(-45.77)\end{array}$ & $\begin{array}{l}0.014^{* * *} \\
(7.55)\end{array}$ \\
\hline Church tax & $\begin{array}{c}0.001 \\
(1.55)\end{array}$ & $\begin{array}{l}-0.000 \\
(-0.32)\end{array}$ & $\begin{array}{l}-0.001 \\
(-1.74)\end{array}$ & $\begin{array}{l}0.002^{* * *} \\
(8.91)\end{array}$ \\
\hline Capital income & $\begin{array}{l}0.002^{* * *} \\
(8.93)\end{array}$ & $\begin{array}{l}0.002^{* * *} \\
(9.50)\end{array}$ & $\begin{array}{l}0.002^{* * *} \\
(11.23)\end{array}$ & $\begin{array}{l}0.001^{* * *} \\
(9.65)\end{array}$ \\
\hline Rent \& lease income & $\begin{array}{l}0.001^{* * *} \\
(4.45)\end{array}$ & $\begin{array}{l}0.001^{* * *} \\
(4.14)\end{array}$ & $\begin{array}{l}0.002^{* * *} \\
(5.53)\end{array}$ & $\begin{array}{l}0.001^{* * *} \\
(6.88)\end{array}$ \\
\hline East Germany & $\begin{array}{l}-0.0109 \\
(-0.76)\end{array}$ & $\begin{array}{l}-0.010 \\
(-0.72)\end{array}$ & $\begin{array}{c}0.008 \\
(0.64)\end{array}$ & $\begin{array}{l}-0.009 \\
(-1.71)\end{array}$ \\
\hline \multicolumn{5}{|c|}{ Assessment type - Reference category: Married, joint assessment } \\
\hline Single female & $\begin{array}{l}-0.096^{* * *} \\
(-12.62)\end{array}$ & $\begin{array}{l}-0.100^{* * *} \\
(-13.00)\end{array}$ & $\begin{array}{l}-0.079^{* * *} \\
(-11.36)\end{array}$ & $\begin{array}{l}-0.035^{* * *} \\
(-7.50)\end{array}$ \\
\hline Single male & $\begin{array}{l}-0.095^{* * *} \\
(-35.05)\end{array}$ & $\begin{array}{l}-0.093^{* * *} \\
(-34.73)\end{array}$ & $\begin{array}{l}-0.075^{* * *} \\
(-30.58)\end{array}$ & $\begin{array}{l}-0.005^{* * *} \\
(-3.62)\end{array}$ \\
\hline Married, separate ass. & $\begin{array}{l}-0.092^{* * *} \\
(-19.14)\end{array}$ & $\begin{array}{l}-0.100^{* * *} \\
(-20.72)\end{array}$ & $\begin{array}{l}-0.099^{* * *} \\
(-20.83)\end{array}$ & $\begin{array}{l}-0.023^{* * *} \\
(-7.33)\end{array}$ \\
\hline \multicolumn{5}{|c|}{ Age groups - Reference category: 45-54 } \\
\hline under 24 years & $\begin{array}{l}-0.027^{* * *} \\
(-6.29)\end{array}$ & $\begin{array}{l}-0.023^{* * *} \\
(-5.44)\end{array}$ & $\begin{array}{r}0.001 \\
(0.24)\end{array}$ & $\begin{array}{l}0.009^{* * *} \\
(5.22)\end{array}$ \\
\hline $25-34$ & $\begin{array}{l}-0.024^{* * *} \\
(-8.72)\end{array}$ & $\begin{array}{l}-0.026^{* * *} \\
(-9.63)\end{array}$ & $\begin{array}{l}-0.026^{* * *} \\
(-10.37)\end{array}$ & $\begin{array}{l}-0.005^{* * *} \\
(-3.82)\end{array}$ \\
\hline $35-44$ & $\begin{array}{c}0.000 \\
(0.03)\end{array}$ & $\begin{array}{l}-0.003 \\
(-1.92)\end{array}$ & $\begin{array}{l}-0.009^{* * *} \\
(-6.10)\end{array}$ & $\begin{array}{l}-0.004^{* * *} \\
(-4.16)\end{array}$ \\
\hline $55-64$ & $\begin{array}{l}-0.010^{* * *} \\
(-5.84)\end{array}$ & $\begin{array}{l}-0.009^{* * *} \\
(-5.26)\end{array}$ & $\begin{array}{l}-0.005^{* *} \\
(-3.07)\end{array}$ & $\begin{array}{l}-0.004^{* * *} \\
(-3.54)\end{array}$ \\
\hline More than 65 years & $\begin{array}{l}-0.019^{* * *} \\
(-6.53)\end{array}$ & $\begin{array}{l}-0.018^{* * *} \\
(-6.30)\end{array}$ & $\begin{array}{l}-0.011^{* * *} \\
(-3.98)\end{array}$ & $\begin{array}{l}-0.002 \\
(-0.86)\end{array}$ \\
\hline \multicolumn{5}{|c|}{ Religious affiliation - Reference category: Other denominations and non-church members } \\
\hline Catholic & $\begin{array}{l}0.068 \\
(0.85)\end{array}$ & $\begin{array}{l}0.068 \\
(0.84)\end{array}$ & $\begin{array}{c}0.018 \\
(0.26)\end{array}$ & $\begin{array}{c}0.008 \\
(0.30)\end{array}$ \\
\hline Protestant & $\begin{array}{c}0.064 \\
(0.80)\end{array}$ & $\begin{array}{c}0.064 \\
(0.79)\end{array}$ & $\begin{array}{c}0.016 \\
(0.23)\end{array}$ & $\begin{array}{r}0.011 \\
(0.41)\end{array}$ \\
\hline \multicolumn{5}{|c|}{ Children - Reference category: no children } \\
\hline One child & $\begin{array}{l}0.018^{* * *} \\
(9.98)\end{array}$ & $\begin{array}{l}0.016^{* * *} \\
(9.07)\end{array}$ & $\begin{array}{l}0.010^{* * *} \\
(6.28)\end{array}$ & $\begin{array}{l}-0.000 \\
(-0.42)\end{array}$ \\
\hline Two children & $\begin{array}{l}0.034^{* * *} \\
(14.28)\end{array}$ & $\begin{array}{l}0.032^{* * *} \\
(13.43)\end{array}$ & $\begin{array}{l}0.024^{* * *} \\
(10.90)\end{array}$ & $\begin{array}{c}0.002 \\
(1.40)\end{array}$ \\
\hline Three children & $\begin{array}{l}0.051^{* * *} \\
(14.28)\end{array}$ & $\begin{array}{l}0.046^{* * *} \\
(12.89)\end{array}$ & $\begin{array}{l}0.040^{* * *} \\
(11.53)\end{array}$ & $\begin{array}{l}0.005^{*} \\
(2.24)\end{array}$ \\
\hline More than three children & $\begin{array}{l}0.057^{* * *} \\
(9.25)\end{array}$ & $\begin{array}{l}0.051^{* * *} \\
(8.31)\end{array}$ & $\begin{array}{l}0.046^{* * *} \\
(7.66)\end{array}$ & $\begin{array}{l}0.011^{*} \\
(2.56)\end{array}$ \\
\hline \multicolumn{5}{|c|}{ Time dummies: Base year 2001} \\
\hline 2002 & $\begin{array}{l}0.011^{* * *} \\
(15.41)\end{array}$ & $\begin{array}{l}0.016^{* * *} \\
(20.70)\end{array}$ & $\begin{array}{l}0.029^{* * *} \\
(40.52)\end{array}$ & $\begin{array}{l}0.010^{* * *} \\
(22.65)\end{array}$ \\
\hline 2003 & $\begin{array}{l}0.004^{* * *} \\
(4.40)\end{array}$ & $\begin{array}{l}0.006^{* * *} \\
(7.46)\end{array}$ & $\begin{array}{l}0.014^{* * *} \\
(18.76)\end{array}$ & $\begin{array}{l}0.004^{* * *} \\
(8.95)\end{array}$ \\
\hline 2004 & $\begin{array}{l}0.031^{* * *} \\
(35.33)\end{array}$ & $\begin{array}{l}0.035^{* * *} \\
(38.96)\end{array}$ & $\begin{array}{l}0.046^{* * *} \\
(55.11)\end{array}$ & $\begin{array}{l}0.012^{* * *} \\
(24.18)\end{array}$ \\
\hline 2005 & $\begin{array}{l}0.047^{* * *} \\
(47.74)\end{array}$ & $\begin{array}{l}0.053^{* * *} \\
(54.29)\end{array}$ & $\begin{array}{l}0.069^{* * *} \\
(75.10)\end{array}$ & $\begin{array}{l}0.021^{* * *} \\
(39.51)\end{array}$ \\
\hline 2006 & $\begin{array}{l}0.025^{* * *} \\
(24.34)\end{array}$ & $\begin{array}{l}0.028^{* * *} \\
(27.04)\end{array}$ & $\begin{array}{l}0.042^{* * *} \\
(44.29)\end{array}$ & $\begin{array}{l}0.013^{* * *} \\
(23.39)\end{array}$ \\
\hline _cons & $\begin{array}{l}0.159^{*} \\
(1.97) \\
\end{array}$ & $\begin{array}{r}0.131 \\
(1.62) \\
\end{array}$ & $\begin{array}{c}0.019 \\
(0.28)\end{array}$ & $\begin{array}{l}-0.162^{* * *} \\
(-5.67)\end{array}$ \\
\hline$N$ & $1,675,235$ & $1,675,235$ & $1,675,235$ & $1,675,235$ \\
\hline
\end{tabular}

Notes: $t$ statistics in parentheses; ${ }^{*} \mathrm{p}<0.05,{ }^{* *} \mathrm{p}<0.01,{ }^{* * *} \mathrm{p}<0.001$. Income, tax price, church tax, capital income, and rent $\&$ lease income are measured in log scale. 
Table A4: Donations at different margins - full table, leavers

\begin{tabular}{|c|c|c|c|c|}
\hline & $\begin{array}{c}(1) \\
\text { Extensive margin }\end{array}$ & $\begin{array}{l}(2) \\
€ 25\end{array}$ & $\begin{array}{l}(3) \\
€ 100\end{array}$ & $\begin{array}{c}(4) \\
€ 1,000\end{array}$ \\
\hline Income & $\begin{array}{l}0.014^{* * *} \\
(28.45)\end{array}$ & $\begin{array}{l}0.011^{* * *} \\
(23.40)\end{array}$ & $\begin{array}{l}0.004^{* * *} \\
(10.67)\end{array}$ & $\begin{array}{l}0.001^{* * *} \\
(10.70)\end{array}$ \\
\hline Tax price & $\begin{array}{l}-0.230^{* * *} \\
(-79.11)\end{array}$ & $\begin{array}{l}-0.231^{* * *} \\
(-82.02)\end{array}$ & $\begin{array}{l}-0.166^{* * *} \\
(-78.26)\end{array}$ & $\begin{array}{l}-0.011^{* * *} \\
(-19.43)\end{array}$ \\
\hline Church tax & $\begin{array}{l}0.001^{* * *} \\
(4.34)\end{array}$ & $\begin{array}{l}0.001^{* *} \\
(3.22)\end{array}$ & $\begin{array}{l}-0.001^{* *} \\
(-2.88)\end{array}$ & $\begin{array}{r}0.000 \\
(0.15)\end{array}$ \\
\hline Capital income & $\begin{array}{l}0.002^{* * *} \\
(9.62)\end{array}$ & $\begin{array}{l}0.003^{* * *} \\
(10.42)\end{array}$ & $\begin{array}{l}0.002^{* * *} \\
(9.96)\end{array}$ & $\begin{array}{l}0.001^{* * *} \\
(7.97)\end{array}$ \\
\hline Rent \& lease income & $\begin{array}{l}0.004^{* * *} \\
(8.83)\end{array}$ & $\begin{array}{l}0.003^{* * *} \\
(8.58)\end{array}$ & $\begin{array}{l}0.003^{* * *} \\
(8.64)\end{array}$ & $\begin{array}{l}0.001^{* * *} \\
(7.19)\end{array}$ \\
\hline East Germany & $\begin{array}{l}-0.010^{* *} \\
(-2.96)\end{array}$ & $\begin{array}{l}-0.011^{* * *} \\
(-3.35)\end{array}$ & $\begin{array}{l}-0.008^{* *} \\
(-3.29)\end{array}$ & $\begin{array}{l}-0.000 \\
(-0.05)\end{array}$ \\
\hline \multicolumn{5}{|c|}{ Assessment type - Reference category: Married, joint assessment } \\
\hline Single female & $\begin{array}{l}-0.090^{* * *} \\
(-19.15)\end{array}$ & $\begin{array}{l}-0.091^{* * *} \\
(-19.90)\end{array}$ & $\begin{array}{l}-0.071^{* * *} \\
(-18.88)\end{array}$ & $\begin{array}{l}-0.014^{* * *} \\
(-8.67)\end{array}$ \\
\hline Single male & $\begin{array}{l}-0.097^{* * *} \\
(-47.22)\end{array}$ & $\begin{array}{l}-0.090^{* * *} \\
(-45.59)\end{array}$ & $\begin{array}{l}-0.057^{* * *} \\
(-36.17)\end{array}$ & $\begin{array}{l}-0.004^{* * *} \\
(-8.34)\end{array}$ \\
\hline Married, separate ass. & $\begin{array}{c}-0.086^{* * *} \\
(-20.82)\end{array}$ & $\begin{array}{l}-0.083^{* * *} \\
(-20.86)\end{array}$ & $\begin{array}{l}-0.065^{* * *} \\
(-19.76)\end{array}$ & $\begin{array}{l}-0.010^{* * *} \\
(-7.60)\end{array}$ \\
\hline Age groups - Reference cat & ory: $45-54$ & & & \\
\hline under 24 years & $\begin{array}{l}-0.009^{* * *} \\
(-3.34)\end{array}$ & $\begin{array}{l}-0.010^{* * *} \\
(-4.01)\end{array}$ & $\begin{array}{l}-0.005^{*} \\
(-2.38)\end{array}$ & $\begin{array}{l}-0.001 \\
(-1.68)\end{array}$ \\
\hline $25-34$ & $\begin{array}{l}-0.007^{* *} \\
(-3.00)\end{array}$ & $\begin{array}{l}-0.012^{* * *} \\
(-5.54)\end{array}$ & $\begin{array}{l}-0.015^{* * *} \\
(-8.79)\end{array}$ & $\begin{array}{l}-0.003^{* * *} \\
(-5.04)\end{array}$ \\
\hline $35-44$ & $\begin{array}{l}0.007^{* * *} \\
(4.19)\end{array}$ & $\begin{array}{c}0.001 \\
(0.77)\end{array}$ & $\begin{array}{l}-0.004^{* *} \\
(-3.00)\end{array}$ & $\begin{array}{l}-0.002^{* * *} \\
(-3.77)\end{array}$ \\
\hline $55-64$ & $\begin{array}{l}-0.008^{* * *} \\
(-4.05)\end{array}$ & $\begin{array}{l}-0.007^{* * *} \\
(-3.38)\end{array}$ & $\begin{array}{l}-0.003 \\
(-1.51)\end{array}$ & $\begin{array}{r}0.001 \\
(1.41)\end{array}$ \\
\hline More than 65 years & $\begin{array}{l}-0.017^{* * *} \\
(-4.58)\end{array}$ & $\begin{array}{l}-0.018^{* * *} \\
(-4.71)\end{array}$ & $\begin{array}{l}-0.005 \\
(-1.62)\end{array}$ & $\begin{array}{r}0.003 \\
(1.90)\end{array}$ \\
\hline \multicolumn{5}{|c|}{ Religious affiliation - Reference category: Other denominations and non-church members } \\
\hline Catholic & $\begin{array}{r}0.001 \\
(0.86)\end{array}$ & $\begin{array}{r}0.001 \\
(0.66)\end{array}$ & $\begin{array}{l}-0.000 \\
(-0.13)\end{array}$ & $\begin{array}{l}-0.003^{* * *} \\
(-5.41)\end{array}$ \\
\hline Protestant & $\begin{array}{r}0.000 \\
(0.12)\end{array}$ & $\begin{array}{l}-0.002 \\
(-1.56)\end{array}$ & $\begin{array}{l}-0.005^{* * *} \\
(-3.98)\end{array}$ & $\begin{array}{l}-0.003^{* * *} \\
(-5.45)\end{array}$ \\
\hline \multicolumn{5}{|c|}{ Children - Reference category: no children } \\
\hline One child & $\begin{array}{l}0.009^{* * *} \\
(5.78)\end{array}$ & $\begin{array}{l}0.008^{* * *} \\
(5.21)\end{array}$ & $\begin{array}{r}0.002 \\
(1.95)\end{array}$ & $\begin{array}{l}-0.000 \\
(-0.82)\end{array}$ \\
\hline Two children & $\begin{array}{l}0.0210^{* * *} \\
(9.91)\end{array}$ & $\begin{array}{l}0.019^{* * *} \\
(9.06)\end{array}$ & $\begin{array}{l}0.010^{* * *} \\
(6.37)\end{array}$ & $\begin{array}{r}0.001 \\
(1.66)\end{array}$ \\
\hline Three children & $\begin{array}{l}0.037^{* * *} \\
(10.06)\end{array}$ & $\begin{array}{l}0.031^{* * * *} \\
(8.91)\end{array}$ & $\begin{array}{l}0.016^{* * *} \\
(5.63)\end{array}$ & $\begin{array}{r}0.002 \\
(1.47)\end{array}$ \\
\hline More than three children & $\begin{array}{l}0.046^{* * *} \\
(6.72)\end{array}$ & $\begin{array}{l}0.039^{* * *} \\
(5.94)\end{array}$ & $\begin{array}{l}0.013^{*} \\
(2.48)\end{array}$ & $\begin{array}{l}0.006^{*} \\
(2.31)\end{array}$ \\
\hline Time dummies: Base year & 001 & & & \\
\hline 2002 & $\begin{array}{l}0.008^{* * *} \\
(16.91)\end{array}$ & $\begin{array}{l}0.010^{* * *} \\
(21.87)\end{array}$ & $\begin{array}{l}0.015^{* * *} \\
(42.08)\end{array}$ & $\begin{array}{l}0.002^{* * *} \\
(14.35)\end{array}$ \\
\hline 2003 & $\begin{array}{l}-0.001^{*} \\
(-2.28)\end{array}$ & $\begin{array}{l}-0.000 \\
(-0.13)\end{array}$ & $\begin{array}{l}0.006^{* * *} \\
(14.80)\end{array}$ & $\begin{array}{l}0.001^{* * *} \\
(7.70)\end{array}$ \\
\hline 2004 & $\begin{array}{l}0.022^{* * *} \\
(32.01)\end{array}$ & $\begin{array}{l}0.022^{* * *} \\
(33.39)\end{array}$ & $\begin{array}{l}0.024^{* * *} \\
(44.60)\end{array}$ & $\begin{array}{l}0.003^{* * *} \\
(14.00)\end{array}$ \\
\hline 2005 & $\begin{array}{l}0.031^{* * *} \\
(35.52)\end{array}$ & $\begin{array}{l}0.032^{* * *} \\
(37.76)\end{array}$ & $\begin{array}{l}0.035^{* * *} \\
(50.75)\end{array}$ & $\begin{array}{l}0.005^{* * *} \\
(18.73)\end{array}$ \\
\hline 2006 & $\begin{array}{l}0.012^{* * *} \\
(12.39)\end{array}$ & $\begin{array}{l}0.012^{* * *} \\
(13.60)\end{array}$ & $\begin{array}{l}0.022^{* * *} \\
(29.45)\end{array}$ & $\begin{array}{l}0.003^{* * *} \\
(10.98)\end{array}$ \\
\hline Constant & $\begin{array}{l}0.099^{* * * *} \\
(19.24)\end{array}$ & $\begin{array}{l}0.106^{* * *} \\
(21.98)\end{array}$ & $\begin{array}{l}0.082^{* * *} \\
(22.01)\end{array}$ & $\begin{array}{l}0.004^{* *} \\
(2.70)\end{array}$ \\
\hline$N$ & $2,815,988$ & $2,815,988$ & $2,815,988$ & $2,815,988$ \\
\hline
\end{tabular}

Notes: $t$ statistics in parentheses; ${ }^{*} \mathrm{p}<0.05,{ }^{* *} \mathrm{p}<0.01,{ }^{* * *} \mathrm{p}<0.001$. Income, tax price, church tax, capital income, and rent \& lease income are measured in log scale. 
Table A5: Donations at different margins - full table, Never-Members

\begin{tabular}{|c|c|c|c|c|}
\hline & $\begin{array}{c}(1) \\
\text { Extensive margin }\end{array}$ & $\begin{array}{l}(2) \\
€ 25\end{array}$ & $\begin{array}{rl} & (3) \\
€ & 100\end{array}$ & $\begin{array}{rl} & (4) \\
€ & 1,000\end{array}$ \\
\hline Income & $\begin{array}{l}0.009^{* * *} \\
(9.15)\end{array}$ & $\begin{array}{l}0.007^{* * *} \\
(7.65)\end{array}$ & $\begin{array}{l}0.006^{* * *} \\
(7.39)\end{array}$ & $\begin{array}{l}0.009^{* * *} \\
(16.62)\end{array}$ \\
\hline Tax price & $\begin{array}{l}-0.274^{* * *} \\
(-88.26)\end{array}$ & $\begin{array}{l}-0.287^{* * *} \\
(-94.16)\end{array}$ & $\begin{array}{l}-0.280^{* * *} \\
(-107.36)\end{array}$ & $\begin{array}{l}-0.031^{* * *} \\
(-30.80)\end{array}$ \\
\hline Capital income & $\begin{array}{l}0.002^{* * *} \\
(6.75)\end{array}$ & $\begin{array}{l}0.002^{* * *} \\
(7.77)\end{array}$ & $\begin{array}{l}0.002^{* * *} \\
(7.98)\end{array}$ & $\begin{array}{l}0.001^{* * *} \\
(5.47)\end{array}$ \\
\hline Rent \& lease income & $\begin{array}{l}0.002^{* * *} \\
(3.55)\end{array}$ & $\begin{array}{l}0.001^{* *} \\
(2.84)\end{array}$ & $\begin{array}{l}0.002^{* * *} \\
(4.91)\end{array}$ & $\begin{array}{l}0.001^{* * *} \\
(4.14)\end{array}$ \\
\hline East Germany & $\begin{array}{l}-0.015 \\
(-1.59)\end{array}$ & $\begin{array}{l}-0.004 \\
(-0.48)\end{array}$ & $\begin{array}{l}-0.007 \\
(-1.22)\end{array}$ & $\begin{array}{c}0.004 \\
(1.19)\end{array}$ \\
\hline \multicolumn{5}{|c|}{ Assessment type - Reference category: Married, joint assessment } \\
\hline Single female & $\begin{array}{l}-0.064^{* * *} \\
(-7.39)\end{array}$ & $\begin{array}{l}-0.059^{* * *} \\
(-7.48)\end{array}$ & $\begin{array}{l}-0.033^{* * *} \\
(-5.63)\end{array}$ & $\begin{array}{l}-0.006 \\
(-1.65)\end{array}$ \\
\hline Single male & $\begin{array}{l}-0.087^{* * *} \\
(-30.51)\end{array}$ & $\begin{array}{l}-0.081^{* * *} \\
(-30.17)\end{array}$ & $\begin{array}{l}-0.033^{* * *} \\
(-15.50)\end{array}$ & $\begin{array}{l}-0.001 \\
(-0.98)\end{array}$ \\
\hline Married, separate ass. & $\begin{array}{l}-0.094^{* * *} \\
(-21.55)\end{array}$ & $\begin{array}{l}-0.093^{* * *} \\
(-22.49)\end{array}$ & $\begin{array}{l}-0.053^{* * *} \\
(-15.24)\end{array}$ & $\begin{array}{l}-0.008^{* * *} \\
(-4.08)\end{array}$ \\
\hline Age groups - Reference cat & ory: $45-54$ & & & \\
\hline under 24 years & $\begin{array}{c}0.009^{*} \\
(2.10)\end{array}$ & $\begin{array}{l}0.012^{* *} \\
(3.26)\end{array}$ & $\begin{array}{l}0.017^{* * *} \\
(6.54)\end{array}$ & $\begin{array}{l}0.008^{* * *} \\
(5.95)\end{array}$ \\
\hline $25-34$ & $\begin{array}{l}-0.005 \\
(-1.73)\end{array}$ & $\begin{array}{l}-0.004 \\
(-1.58)\end{array}$ & $\begin{array}{l}-0.001 \\
(-0.69)\end{array}$ & $\begin{array}{c}0.001 \\
(1.37)\end{array}$ \\
\hline $35-44$ & $\begin{array}{l}-0.000 \\
(-0.07)\end{array}$ & $\begin{array}{l}-0.002 \\
(-1.06)\end{array}$ & $\begin{array}{l}-0.003^{*} \\
(-2.44)\end{array}$ & $\begin{array}{l}-0.001 \\
(-0.99)\end{array}$ \\
\hline $55-64$ & $\begin{array}{l}-0.003 \\
(-1.64)\end{array}$ & $\begin{array}{l}-0.003 \\
(-1.35)\end{array}$ & $\begin{array}{c}0.000 \\
(0.24)\end{array}$ & $\begin{array}{l}-0.001 \\
(-1.57)\end{array}$ \\
\hline More than 65 years & $\begin{array}{l}-0.008 \\
(-1.88)\end{array}$ & $\begin{array}{l}-0.008^{*} \\
(-2.19)\end{array}$ & $\begin{array}{r}0.001 \\
(0.22)\end{array}$ & $\begin{array}{l}0.00277 \\
(1.31)\end{array}$ \\
\hline Children - Reference catego & : no children & & & \\
\hline One child & $\begin{array}{l}0.009^{* * *} \\
(5.01)\end{array}$ & $\begin{array}{l}0.008^{* * *} \\
(4.85)\end{array}$ & $\begin{array}{l}0.007^{* * *} \\
(5.85)\end{array}$ & $\begin{array}{l}0.002^{*} \\
(2.40)\end{array}$ \\
\hline Two children & $\begin{array}{l}0.021^{* * *} \\
(8.71)\end{array}$ & $\begin{array}{l}0.019^{* * *} \\
(8.22)\end{array}$ & $\begin{array}{l}0.013^{* * *} \\
(7.86)\end{array}$ & $\begin{array}{l}0.003^{* *} \\
(2.77)\end{array}$ \\
\hline Three children & $\begin{array}{l}0.029^{* * *} \\
(7.29)\end{array}$ & $\begin{array}{l}0.026^{* * *} \\
(6.87)\end{array}$ & $\begin{array}{l}0.022^{* * *} \\
(7.15)\end{array}$ & $\begin{array}{c}0.003 \\
(1.83)\end{array}$ \\
\hline More than three children & $\begin{array}{l}0.031^{* * *} \\
(4.38)\end{array}$ & $\begin{array}{l}0.030^{* * *} \\
(4.41)\end{array}$ & $\begin{array}{l}0.027^{* * *} \\
(4.87)\end{array}$ & $\begin{array}{l}0.007^{*} \\
(2.12)\end{array}$ \\
\hline Time dummies: Base year & 001 & & & \\
\hline 2002 & $\begin{array}{l}0.009^{* * *} \\
(9.70)\end{array}$ & $\begin{array}{l}0.009^{* * *} \\
(10.50)\end{array}$ & $\begin{array}{l}0.013^{* * *} \\
(19.61)\end{array}$ & $\begin{array}{l}0.005^{* * *} \\
(13.67)\end{array}$ \\
\hline 2003 & $\begin{array}{l}-0.007^{* * *} \\
(-7.03)\end{array}$ & $\begin{array}{l}-0.006^{* * *} \\
(-6.64)\end{array}$ & $\begin{array}{l}0.002^{* * *} \\
(3.44)\end{array}$ & $\begin{array}{l}0.002^{* * *} \\
(3.79)\end{array}$ \\
\hline 2004 & $\begin{array}{l}0.018^{* * *} \\
(17.75)\end{array}$ & $\begin{array}{l}0.018^{* * *} \\
(17.72)\end{array}$ & $\begin{array}{l}0.021^{* * *} \\
(28.24)\end{array}$ & $\begin{array}{l}0.006^{* * *} \\
(14.23)\end{array}$ \\
\hline 2005 & $\begin{array}{l}0.035^{* * *} \\
(31.33)\end{array}$ & $\begin{array}{l}0.035^{* * * *} \\
(32.82)\end{array}$ & $\begin{array}{l}0.039^{* * *} \\
(47.04)\end{array}$ & $\begin{array}{l}0.012^{* * *} \\
(25.44)\end{array}$ \\
\hline 2006 & $\begin{array}{l}0.011^{* * *} \\
(9.14)\end{array}$ & $\begin{array}{l}0.010^{* * *} \\
(8.79)\end{array}$ & $\begin{array}{l}0.018^{* * *} \\
(21.39)\end{array}$ & $\begin{array}{l}0.006^{* * *} \\
(13.14)\end{array}$ \\
\hline Constant & $\begin{array}{l}0.145^{* * *} \\
(12.69)\end{array}$ & $\begin{array}{l}0.128^{* * *} \\
(11.86)\end{array}$ & $\begin{array}{l}0.034^{* * *} \\
(3.87)\end{array}$ & $\begin{array}{c}-0.064^{* * *} \\
(-10.62)\end{array}$ \\
\hline$N$ & $1,057,284$ & $1,057,284$ & $1,057,284$ & $1,057,284$ \\
\hline
\end{tabular}

Notes: $t$ statistics in parentheses; ${ }^{*} \mathrm{p}<0.05,{ }^{* *} \mathrm{p}<0.01,{ }^{* * *} \mathrm{p}<0.001$. Income, tax price, capital income, and rent $\&$ lease income are measured in log scale. 
Table A6: Church tax effects on scientific donations - full table

\begin{tabular}{|c|c|c|c|c|}
\hline & $\begin{array}{l}(1) \\
5 \% \text { sample }\end{array}$ & $\begin{array}{c}(2) \\
\text { Members }\end{array}$ & $\begin{array}{c}(3) \\
\text { Leavers }\end{array}$ & $\begin{array}{c}(4) \\
\text { Non-Members }\end{array}$ \\
\hline Income & $\begin{array}{l}0.514^{* * *} \\
(3.49)\end{array}$ & $\begin{array}{l}0.607^{* *} \\
(3.19)\end{array}$ & $\begin{array}{l}0.569^{* * *} \\
(4.40)\end{array}$ & $\begin{array}{l}0.441^{* * *} \\
(3.97)\end{array}$ \\
\hline Tax price & $\begin{array}{l}-0.172 \\
(-0.46)\end{array}$ & $\begin{array}{l}-0.455 \\
(-1.15)\end{array}$ & $\begin{array}{l}-1.061^{* * *} \\
(-3.88)\end{array}$ & $\begin{array}{l}-0.784^{*} \\
(-2.06)\end{array}$ \\
\hline Church tax & $\begin{array}{c}0.037 \\
(1.19)\end{array}$ & $\begin{array}{c}0.006 \\
(0.20)\end{array}$ & $\begin{array}{c}0.003 \\
(0.25)\end{array}$ & \\
\hline Capital income & $\begin{array}{l}0.022^{* *} \\
(2.97)\end{array}$ & $\begin{array}{l}0.023^{* * *} \\
(3.45)\end{array}$ & $\begin{array}{l}0.024^{*} \\
(2.54)\end{array}$ & $\begin{array}{c}0.025 \\
(1.17)\end{array}$ \\
\hline Rent \& lease income & $\begin{array}{l}-0.022 \\
(-0.65)\end{array}$ & $\begin{array}{l}-0.032 \\
(-0.82)\end{array}$ & $\begin{array}{c}0.016 \\
(0.86)\end{array}$ & $\begin{array}{l}0.018 \\
(0.64)\end{array}$ \\
\hline East Germany & $\begin{array}{c}0.163 \\
(0.65)\end{array}$ & $\begin{array}{c}0.254 \\
(0.86)\end{array}$ & $\begin{array}{c}0.112 \\
(1.02)\end{array}$ & $\begin{array}{l}-0.052 \\
(-0.12)\end{array}$ \\
\hline \multicolumn{5}{|c|}{ Assessment type - Reference category: Married, joint assessment } \\
\hline Single female & $\begin{array}{l}-0.571^{* * *} \\
(-3.38)\end{array}$ & $\begin{array}{l}-0.730^{* * *} \\
(-3.78)\end{array}$ & $\begin{array}{l}-0.355^{* *} \\
(-3.15)\end{array}$ & $\begin{array}{c}0.183 \\
(0.35)\end{array}$ \\
\hline Single male & $\begin{array}{l}-0.220 \\
(-1.44)\end{array}$ & $\begin{array}{l}-0.249 \\
(-1.32)\end{array}$ & $\begin{array}{l}-0.256^{* *} \\
(-2.86)\end{array}$ & $\begin{array}{c}0.270 \\
(1.02)\end{array}$ \\
\hline Married, separate ass. & $\begin{array}{l}-0.218 \\
(-1.12)\end{array}$ & $\begin{array}{l}-0.438^{*} \\
(-2.16)\end{array}$ & $\begin{array}{l}-0.270^{*} \\
(-2.20)\end{array}$ & $\begin{array}{l}-0.908^{* *} \\
(-2.85)\end{array}$ \\
\hline Age groups - Reference cat & $y: 45-54$ & & & \\
\hline under 24 years & $\begin{array}{l}-0.508 \\
(-1.11)\end{array}$ & $\begin{array}{l}-0.837^{*} \\
(-2.06)\end{array}$ & $\begin{array}{c}0.116 \\
(0.37)\end{array}$ & $\begin{array}{l}-1.205^{*} \\
(-2.15)\end{array}$ \\
\hline $25-34$ & $\begin{array}{l}-0.743^{* *} \\
(-3.20)\end{array}$ & $\begin{array}{l}-0.677^{* *} \\
(-2.62)\end{array}$ & $\begin{array}{l}-0.170 \\
(-1.32)\end{array}$ & $\begin{array}{l}-1.161^{* *} \\
(-3.25)\end{array}$ \\
\hline $35-44$ & $\begin{array}{l}-0.433^{* *} \\
(-2.58)\end{array}$ & $\begin{array}{l}-0.432^{*} \\
(-2.20)\end{array}$ & $\begin{array}{l}-0.001 \\
(-0.01)\end{array}$ & $\begin{array}{l}-0.442^{*} \\
(-2.40)\end{array}$ \\
\hline $55-64$ & $\begin{array}{c}0.130 \\
(0.49)\end{array}$ & $\begin{array}{c}0.043 \\
(0.14)\end{array}$ & $\begin{array}{c}0.021 \\
(0.26)\end{array}$ & $\begin{array}{l}0.568^{*} \\
(2.40)\end{array}$ \\
\hline More than 65 years & $\begin{array}{l}0.794^{*} \\
(2.52)\end{array}$ & $\begin{array}{r}0.581 \\
(1.47)\end{array}$ & $\begin{array}{l}-0.025 \\
(-0.16)\end{array}$ & $\begin{array}{l}1.440^{* * *} \\
(3.70)\end{array}$ \\
\hline \multicolumn{5}{|c|}{ Religious affiliation - Reference category: Other denominations and non-church members } \\
\hline Catholic & $\begin{array}{c}0.045 \\
(0.18)\end{array}$ & $\begin{array}{r}0.067 \\
(0.12)\end{array}$ & $\begin{array}{c}0.016 \\
(0.24)\end{array}$ & \\
\hline Protestant & $\begin{array}{l}-0.405 \\
(-1.70)\end{array}$ & $\begin{array}{l}-0.433 \\
(-0.72)\end{array}$ & $\begin{array}{l}-0.076 \\
(-0.90)\end{array}$ & \\
\hline \multicolumn{5}{|c|}{ Children - Reference category: no children } \\
\hline One child & $\begin{array}{c}0.060 \\
(0.46)\end{array}$ & $\begin{array}{c}0.162 \\
(0.95)\end{array}$ & $\begin{array}{l}-0.032 \\
(-0.63)\end{array}$ & $\begin{array}{l}-0.128 \\
(-0.74)\end{array}$ \\
\hline Two children & $\begin{array}{l}-0.006 \\
(-0.04)\end{array}$ & $\begin{array}{c}0.092 \\
(0.54)\end{array}$ & $\begin{array}{l}-0.071 \\
(-0.76)\end{array}$ & $\begin{array}{c}0.006 \\
(0.03)\end{array}$ \\
\hline Three children & $\begin{array}{c}0.083 \\
(0.48)\end{array}$ & $\begin{array}{c}0.209 \\
(1.00)\end{array}$ & $\begin{array}{l}-0.155 \\
(-1.34)\end{array}$ & $\begin{array}{l}-0.492 \\
(-1.38)\end{array}$ \\
\hline More than three children & $\begin{array}{c}0.121 \\
(0.59)\end{array}$ & $\begin{array}{c}0.278 \\
(1.12)\end{array}$ & $\begin{array}{l}-0.075 \\
(-0.45)\end{array}$ & $\begin{array}{l}-0.228 \\
(-0.75)\end{array}$ \\
\hline Time dummies: Base year & & & & \\
\hline 2002 & $\begin{array}{l}0.220^{*} \\
(1.97)\end{array}$ & $\begin{array}{c}0.006 \\
(0.05)\end{array}$ & $\begin{array}{l}0.213^{* * *} \\
(4.02)\end{array}$ & $\begin{array}{c}0.360 \\
(1.87)\end{array}$ \\
\hline 2003 & $\begin{array}{c}0.040 \\
(0.28)\end{array}$ & $\begin{array}{c}0.059 \\
(0.43)\end{array}$ & $\begin{array}{c}0.108 \\
(1.79)\end{array}$ & $\begin{array}{c}-0.419 \\
(-1.81)\end{array}$ \\
\hline 2004 & $\begin{array}{l}-0.125 \\
(-1.03)\end{array}$ & $\begin{array}{c}-0.139 \\
(-0.99)\end{array}$ & $\begin{array}{l}0.308^{* *} \\
(2.63)\end{array}$ & $\begin{array}{c}-0.472 \\
(-1.92)\end{array}$ \\
\hline 2005 & $\begin{array}{c}-0.014 \\
(-0.09)\end{array}$ & $\begin{array}{l}-0.207 \\
(-1.24)\end{array}$ & $\begin{array}{l}0.406^{* * *} \\
(5.60)\end{array}$ & $\begin{array}{c}0.087 \\
(0.33)\end{array}$ \\
\hline 2006 & $\begin{array}{c}0.021 \\
(0.15)\end{array}$ & $\begin{array}{c}0.056 \\
(0.41)\end{array}$ & $\begin{array}{l}0.406^{* * *} \\
(3.77)\end{array}$ & $\begin{array}{c}-0.333 \\
(-1.18)\end{array}$ \\
\hline$N$ & 810,064 & 601,817 & 513,455 & 251,974 \\
\hline
\end{tabular}

Notes: $t$ statistics in parentheses; ${ }^{*} \mathrm{p}<0.05,{ }^{* *} \mathrm{p}<0.01,{ }^{* * *} \mathrm{p}<0.001$. Income, tax price church tax, capital income, and rent \& lease income are measured in log scale. 
Table A7: Non-donor effect on church exit - full table

\begin{tabular}{|c|c|c|c|c|}
\hline & (1) & $(2)$ & (3) & $(4)$ \\
\hline Non-donor & $\begin{array}{l}0.015^{* * *} \\
(11.59)\end{array}$ & $\begin{array}{l}0.050^{* * *} \\
(17.54)\end{array}$ & $\begin{array}{l}0.020^{* * *} \\
(14.77)\end{array}$ & $\begin{array}{l}0.012^{* * *} \\
(9.07)\end{array}$ \\
\hline Income & $\begin{array}{l}-0.034^{* * *} \\
(-29.89)\end{array}$ & $\begin{array}{l}-0.033^{* * *} \\
(-29.09)\end{array}$ & $\begin{array}{l}-0.033^{* * *} \\
(-29.09)\end{array}$ & $\begin{array}{l}-0.033^{* * *} \\
(-29.09)\end{array}$ \\
\hline Tax price & $\begin{array}{c}0.229^{* * *} \\
(55.72)\end{array}$ & $\begin{array}{l}0.228^{* * *} \\
(55.58)\end{array}$ & $\begin{array}{l}0.228^{* * *} \\
(55.58)\end{array}$ & $\begin{array}{l}0.228^{* * *} \\
(55.58)\end{array}$ \\
\hline Church tax & $\begin{array}{l}0.033^{* * *} \\
(85.49)\end{array}$ & $\begin{array}{l}0.039^{* * *} \\
(68.07)\end{array}$ & $\begin{array}{l}0.039^{* * *} \\
(68.07)\end{array}$ & $\begin{array}{l}0.039^{* * *} \\
(68.07)\end{array}$ \\
\hline Non-donor \# Church tax & & $\begin{array}{l}-0.007^{* * *} \\
(-13.73)\end{array}$ & & \\
\hline Non-donor \# Church tax (at mean) & & & $\begin{array}{l}-0.007^{* * *} \\
(-13.73)\end{array}$ & \\
\hline Non-donor \# Church tax (at median) & & & & $\begin{array}{l}-0.007^{* * *} \\
(-13.73)\end{array}$ \\
\hline Capital income & $\begin{array}{l}-0.003^{* * *} \\
(-8.10)\end{array}$ & $\begin{array}{l}-0.003^{* * *} \\
(-8.28)\end{array}$ & $\begin{array}{l}-0.003^{* * *} \\
(-8.28)\end{array}$ & $\begin{array}{l}-0.003^{* * *} \\
(-8.28)\end{array}$ \\
\hline Rent\& lease income & $\begin{array}{l}-0.009^{* * *} \\
(-13.91)\end{array}$ & $\begin{array}{l}-0.009^{* * *} \\
(-13.99)\end{array}$ & $\begin{array}{l}-0.009^{* * *} \\
(-13.99)\end{array}$ & $\begin{array}{l}-0.009^{* * *} \\
(-13.99)\end{array}$ \\
\hline East Germany & $\begin{array}{l}-0.060^{* * *} \\
(-6.92)\end{array}$ & $\begin{array}{l}-0.060^{* * *} \\
(-6.92)\end{array}$ & $\begin{array}{l}-0.060^{* * *} \\
(-6.92)\end{array}$ & $\begin{array}{l}-0.060^{* * *} \\
(-6.92)\end{array}$ \\
\hline Children dummy ( $1=$ yes $)$ & $\begin{array}{l}0.007^{* *} \\
(2.63)\end{array}$ & $\begin{array}{l}0.007^{* *} \\
(2.63)\end{array}$ & $\begin{array}{l}0.007^{* *} \\
(2.63)\end{array}$ & $\begin{array}{l}0.007^{* *} \\
(2.63)\end{array}$ \\
\hline \multicolumn{5}{|c|}{ Assessment type - Reference category: Married, joint assessment } \\
\hline Single female & $\begin{array}{l}0.271^{* * *} \\
(33.36)\end{array}$ & $\begin{array}{l}0.271^{* * *} \\
(33.30)\end{array}$ & $\begin{array}{l}0.271^{* * *} \\
(33.30)\end{array}$ & $\begin{array}{l}0.271^{* * *} \\
(33.30)\end{array}$ \\
\hline Single male & $\begin{array}{l}0.197^{* * *} \\
(60.19)\end{array}$ & $\begin{array}{l}0.197^{* * *} \\
(60.41)\end{array}$ & $\begin{array}{l}0.197^{* * *} \\
(60.41)\end{array}$ & $\begin{array}{l}0.197^{* * *} \\
(60.41)\end{array}$ \\
\hline Married, separate ass. & $\begin{array}{l}0.185^{* * *} \\
(29.52)\end{array}$ & $\begin{array}{l}0.185^{* * *} \\
(29.57)\end{array}$ & $\begin{array}{l}0.185^{* * *} \\
(29.57)\end{array}$ & $\begin{array}{l}0.185^{* * *} \\
(29.57)\end{array}$ \\
\hline $\begin{array}{l}\text { Age groups - Reference category: } 45-54 \\
\text { under } 24 \text { years }\end{array}$ & $\begin{array}{l}-0.023^{* * *} \\
(-5.23)\end{array}$ & $\begin{array}{l}-0.022^{* * *} \\
(-5.15)\end{array}$ & $\begin{array}{l}-0.022^{* * *} \\
(-5.15)\end{array}$ & $\begin{array}{l}-0.022^{* * *} \\
(-5.15)\end{array}$ \\
\hline $25-34$ & $\begin{array}{l}0.029^{* * *} \\
(8.44)\end{array}$ & $\begin{array}{l}0.030^{* * *} \\
(8.59)\end{array}$ & $\begin{array}{l}0.030^{* * *} \\
(8.59)\end{array}$ & $\begin{array}{l}0.030^{* * *} \\
(8.59)\end{array}$ \\
\hline $35-44$ & $\begin{array}{l}0.040^{* * *} \\
(16.31)\end{array}$ & $\begin{array}{l}0.040^{* * *} \\
(16.39)\end{array}$ & $\begin{array}{l}0.0400^{* * *} \\
(16.39)\end{array}$ & $\begin{array}{l}0.0400^{* * *} \\
(16.39)\end{array}$ \\
\hline $55-64$ & $\begin{array}{l}-0.047^{* * *} \\
(-14.46)\end{array}$ & $\begin{array}{l}-0.047^{* * *} \\
(-14.45)\end{array}$ & $\begin{array}{l}-0.047^{* * *} \\
(-14.45)\end{array}$ & $\begin{array}{l}-0.047^{* * *} \\
(-14.45)\end{array}$ \\
\hline More than 65 years & $\begin{array}{l}-0.038^{* * *} \\
(-5.61)\end{array}$ & $\begin{array}{l}-0.037^{* * *} \\
(-5.47)\end{array}$ & $\begin{array}{l}-0.037^{* * *} \\
(-5.47)\end{array}$ & $\begin{array}{l}-0.037^{* * *} \\
(-5.47)\end{array}$ \\
\hline 2002 & $\begin{array}{l}-0.541^{* * *} \\
(-351.99)\end{array}$ & $\begin{array}{l}-0.541^{* * *} \\
(-352.16)\end{array}$ & $\begin{array}{l}-0.541^{* * *} \\
(-352.16)\end{array}$ & $\begin{array}{l}-0.541^{* * *} \\
(-352.16)\end{array}$ \\
\hline 2003 & $\begin{array}{l}-0.375^{* * *} \\
(-244.60)\end{array}$ & $\begin{array}{l}-0.375^{* * *} \\
(-244.77)\end{array}$ & $\begin{array}{l}-0.375^{* * *} \\
(-244.77)\end{array}$ & $\begin{array}{l}-0.375^{* * *} \\
(-244.77)\end{array}$ \\
\hline 2004 & $\begin{array}{l}-0.236^{* * *} \\
(-152.39)\end{array}$ & $\begin{array}{l}-0.237^{* * *} \\
(-152.49)\end{array}$ & $\begin{array}{l}-0.237^{* * *} \\
(-152.49)\end{array}$ & $\begin{array}{l}-0.237^{* * *} \\
(-152.49)\end{array}$ \\
\hline 2005 & $\begin{array}{c}-0.019^{* * *} \\
(-12.20)\end{array}$ & $\begin{array}{c}-0.019^{* * *} \\
(-12.26)\end{array}$ & $\begin{array}{c}-0.019^{* * *} \\
(-12.26)\end{array}$ & $\begin{array}{c}-0.019^{* * *} \\
(-12.26)\end{array}$ \\
\hline Constant & $\begin{array}{l}0.692^{* * *} \\
(59.47)\end{array}$ & $\begin{array}{l}0.652^{* * *} \\
(54.58)\end{array}$ & $\begin{array}{l}0.652^{* * *} \\
(54.58)\end{array}$ & $\begin{array}{l}0.652^{* * *} \\
(54.58)\end{array}$ \\
\hline$N$ & $2,466,328$ & $2,466,328$ & $2,466,328$ & $2,466,328$ \\
\hline
\end{tabular}

Notes: $t$ statistics in parentheses; ${ }^{*} \mathrm{p}<0.05,{ }^{* *} \mathrm{p}<0.01,{ }^{* * *} \mathrm{p}<0.001$. Income, tax price, church tax, capital income, and rent \& lease income are measured in log scale. All control variables are measured at $\mathrm{t}-1$. 
Table A8: Donations after church exit - full table

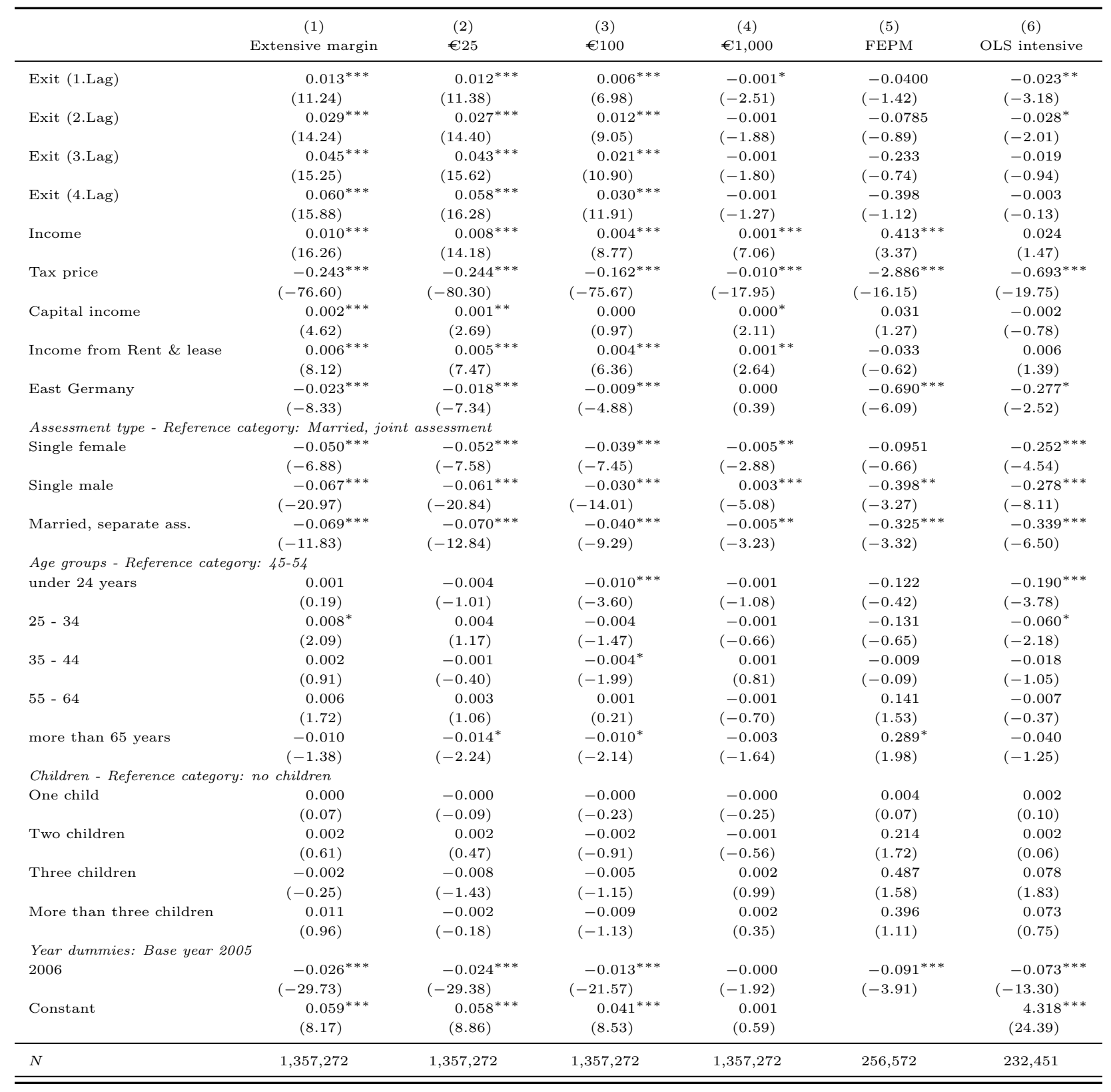

Notes: $t$ statistics in parentheses; ${ }^{*} \mathrm{p}<0.05,{ }^{* *} \mathrm{p}<0.01,{ }^{* * *} \mathrm{p}<0.001$. Income, tax price, capital income, and rent \& lease income are measured in log scale. 

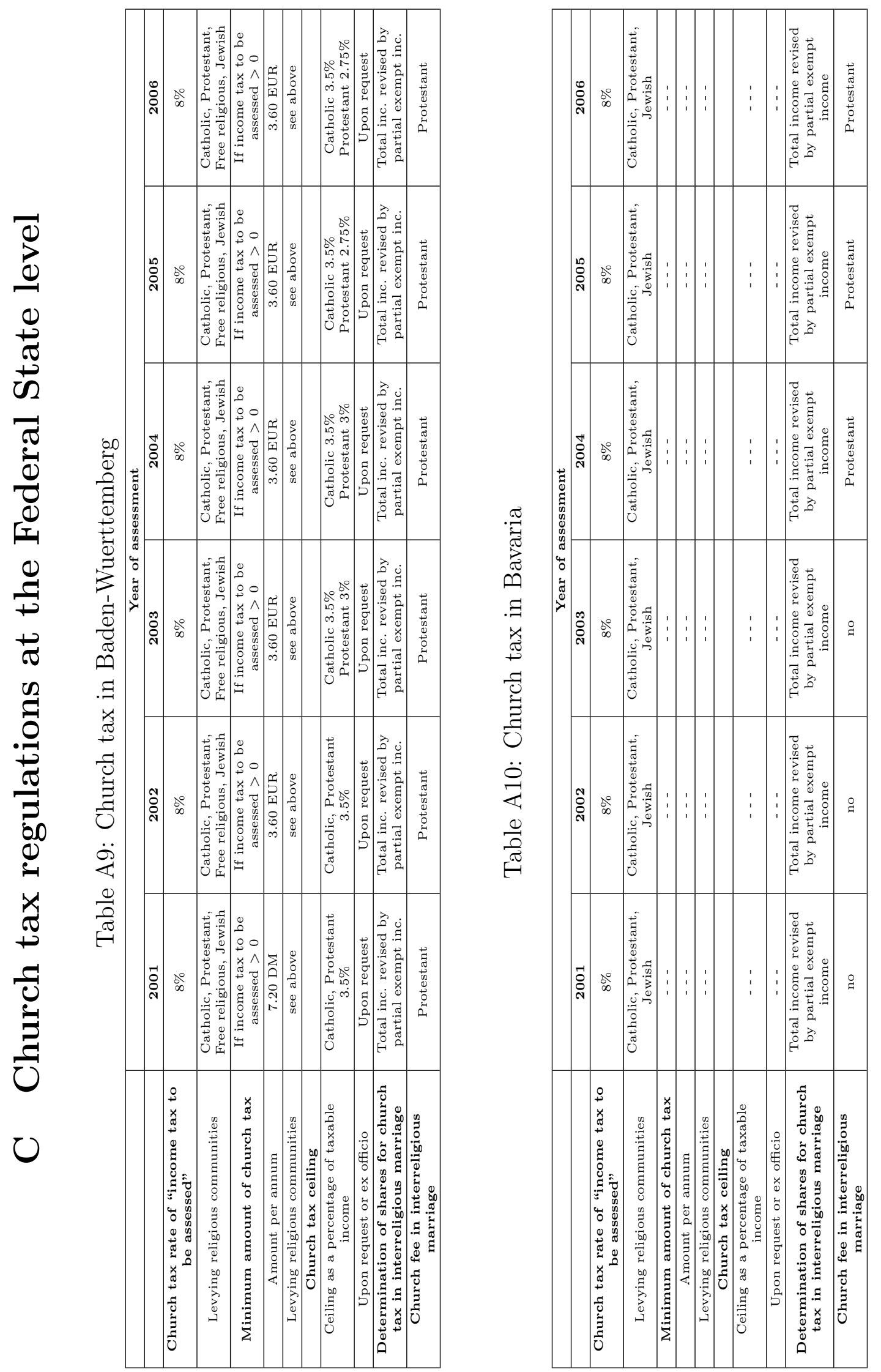

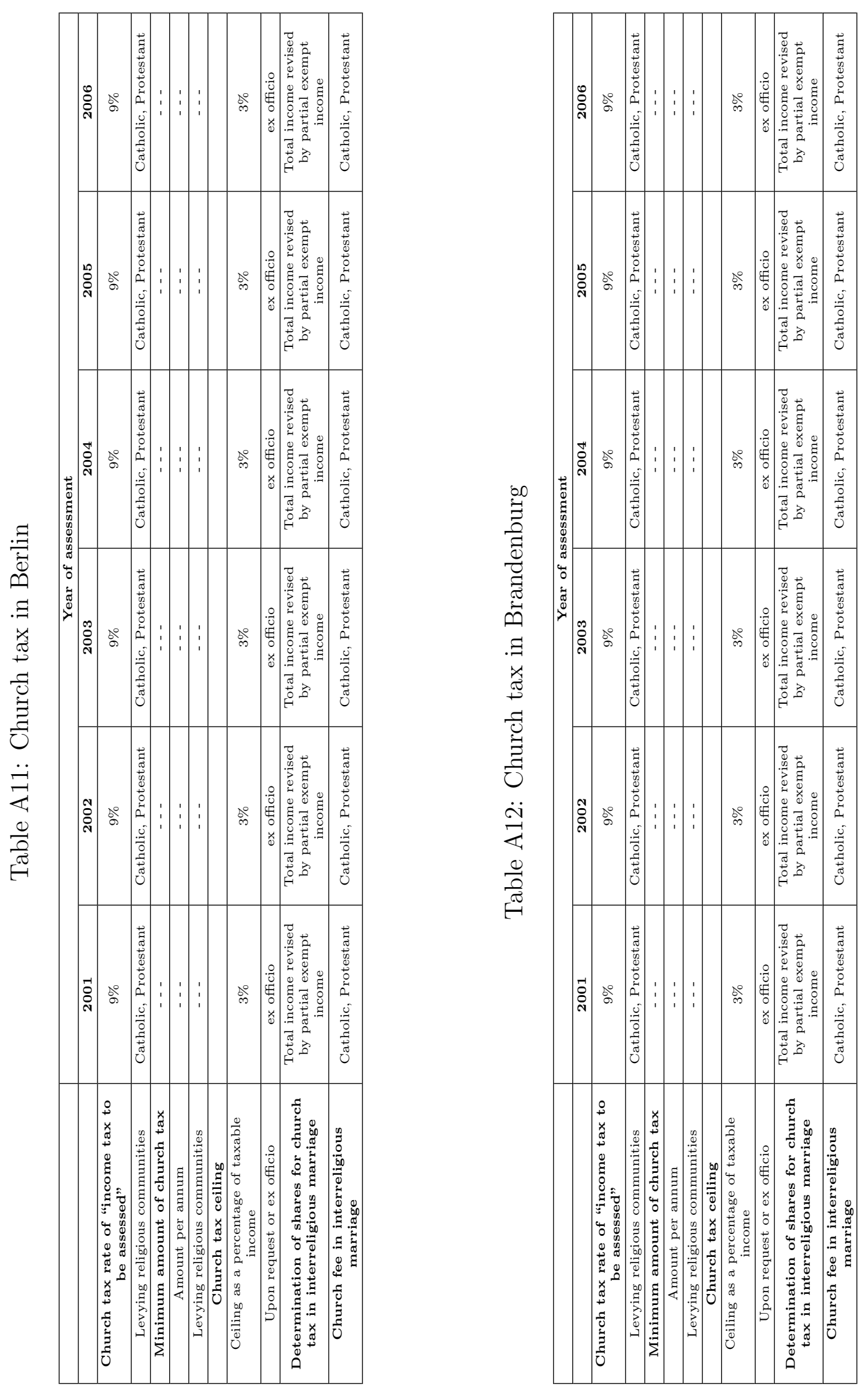

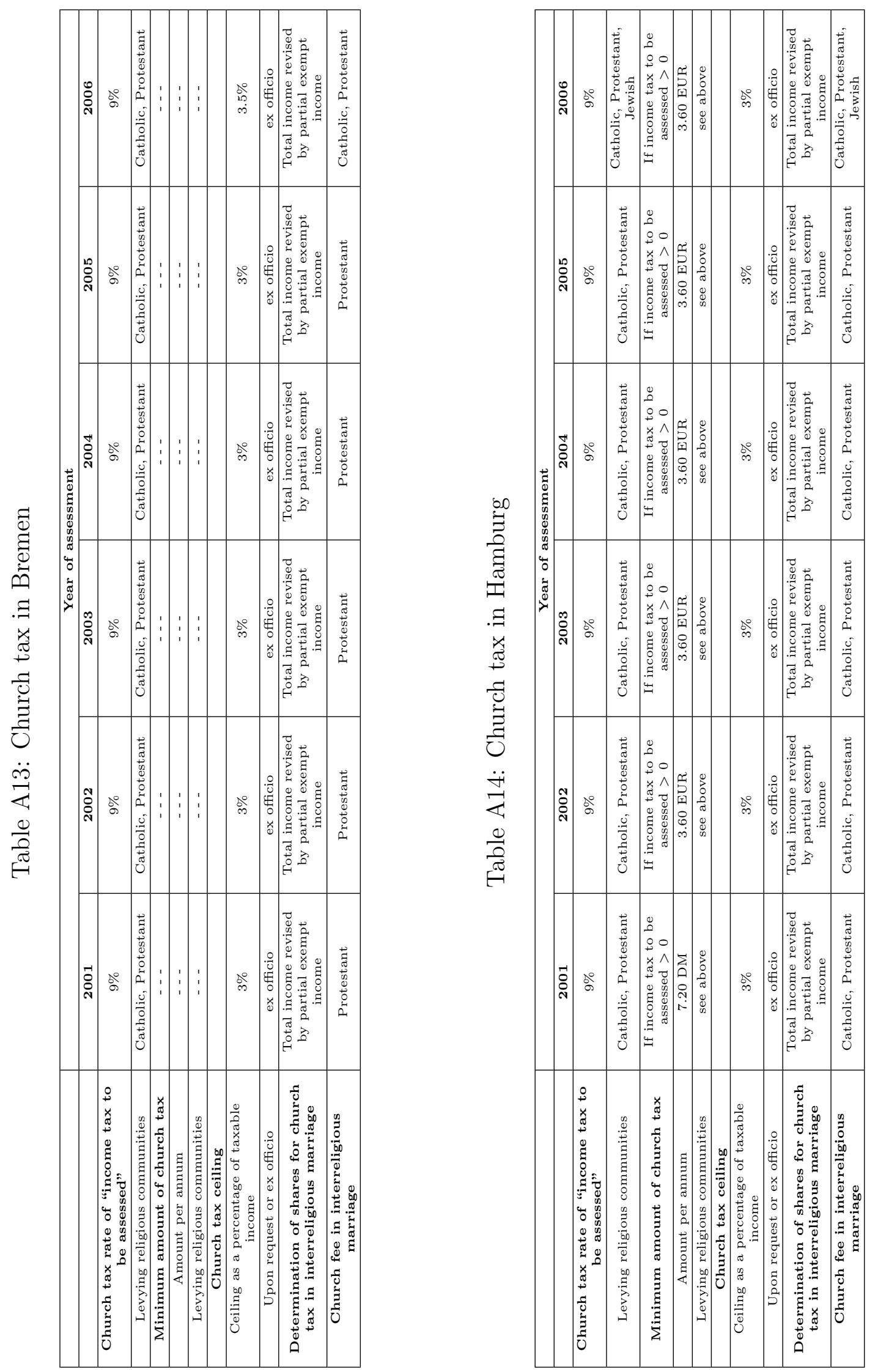

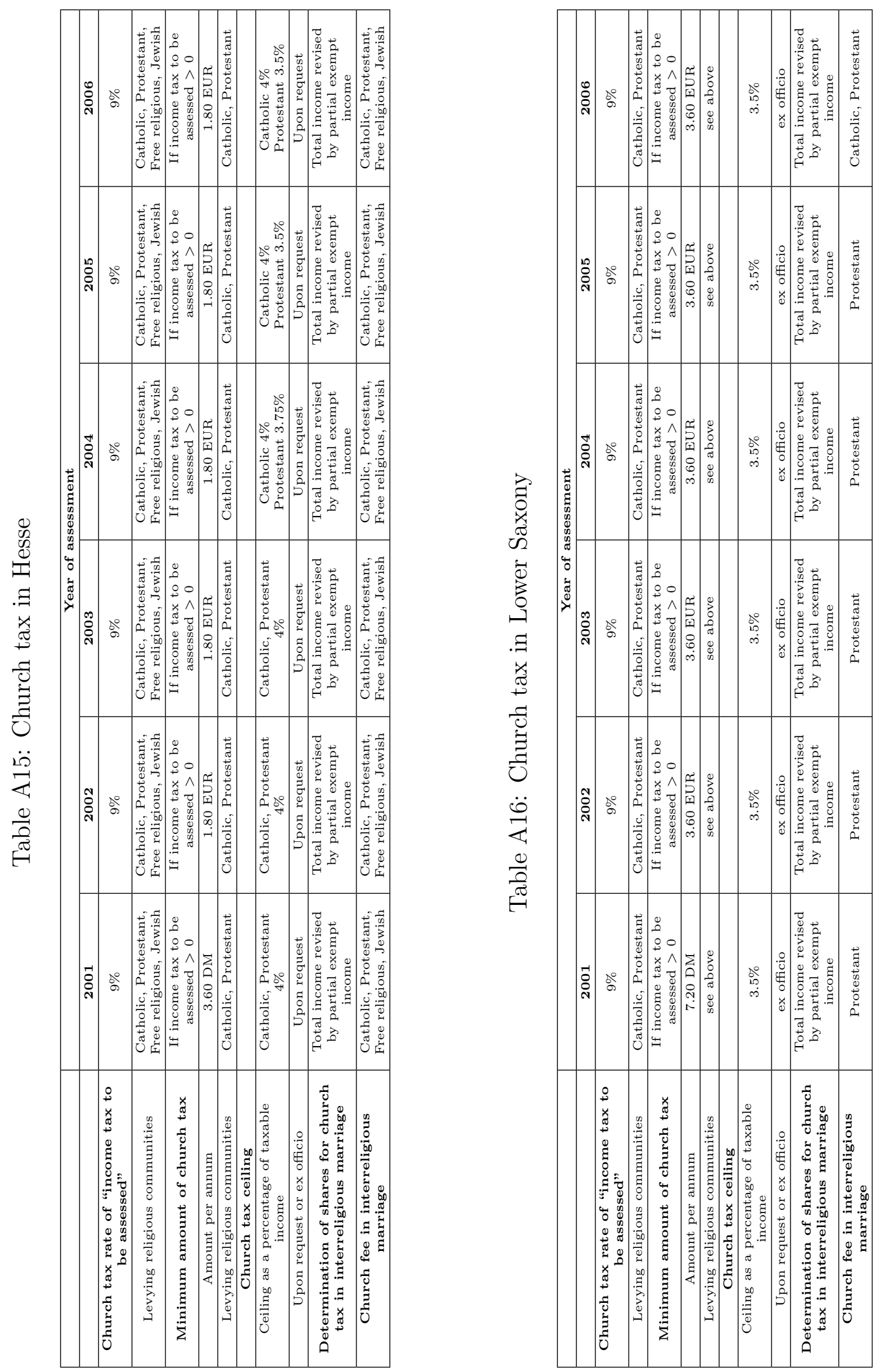

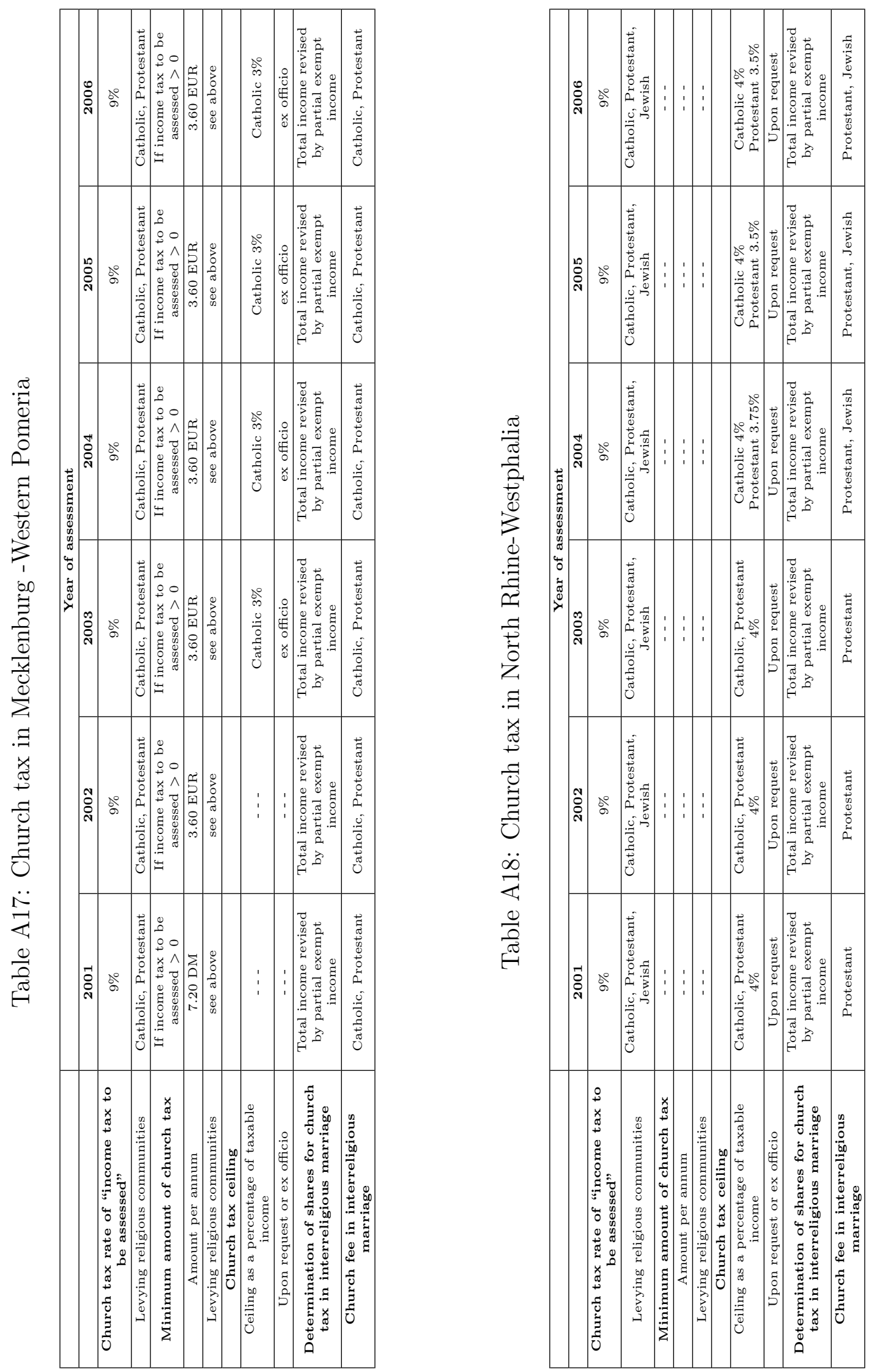

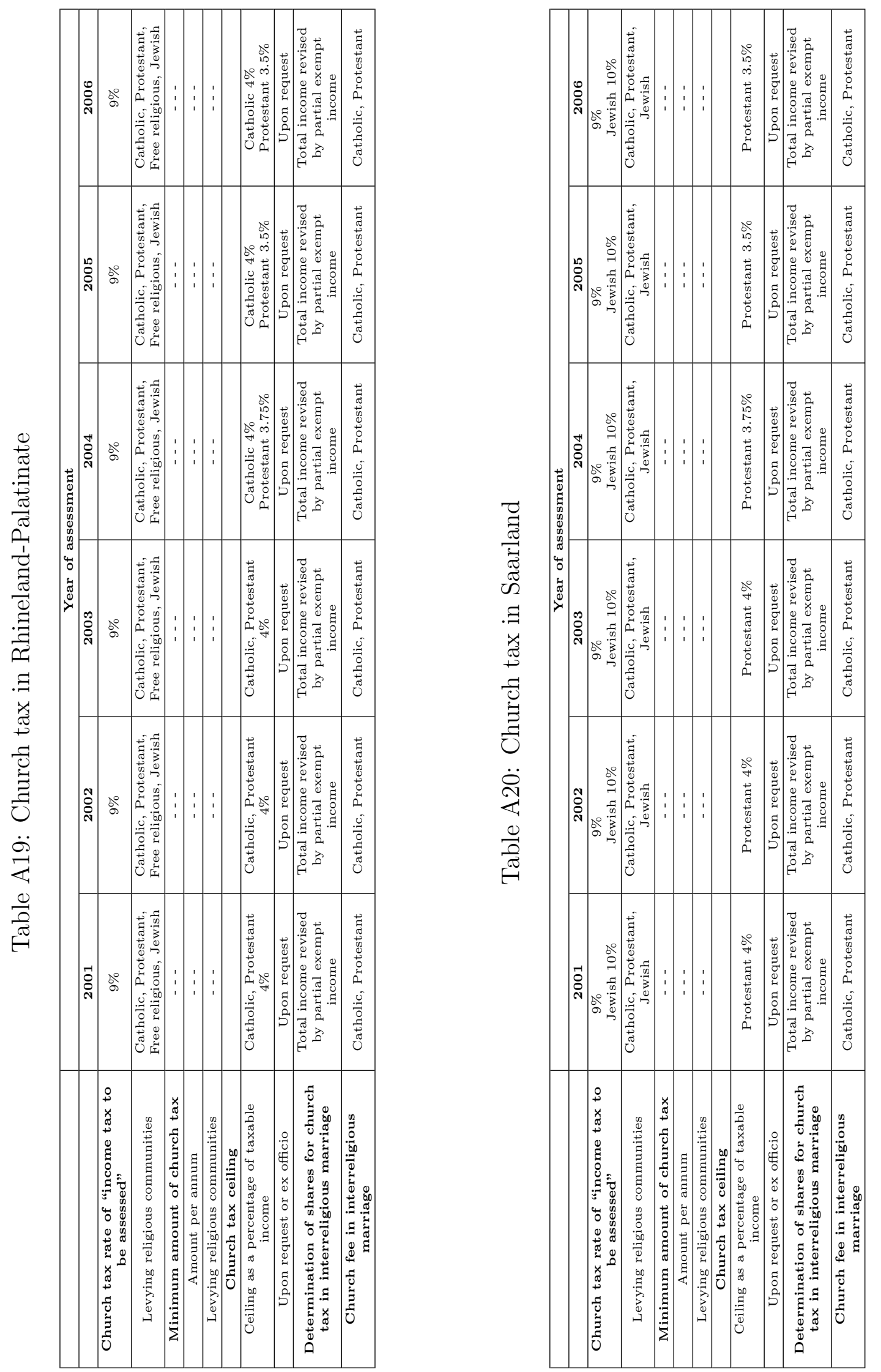

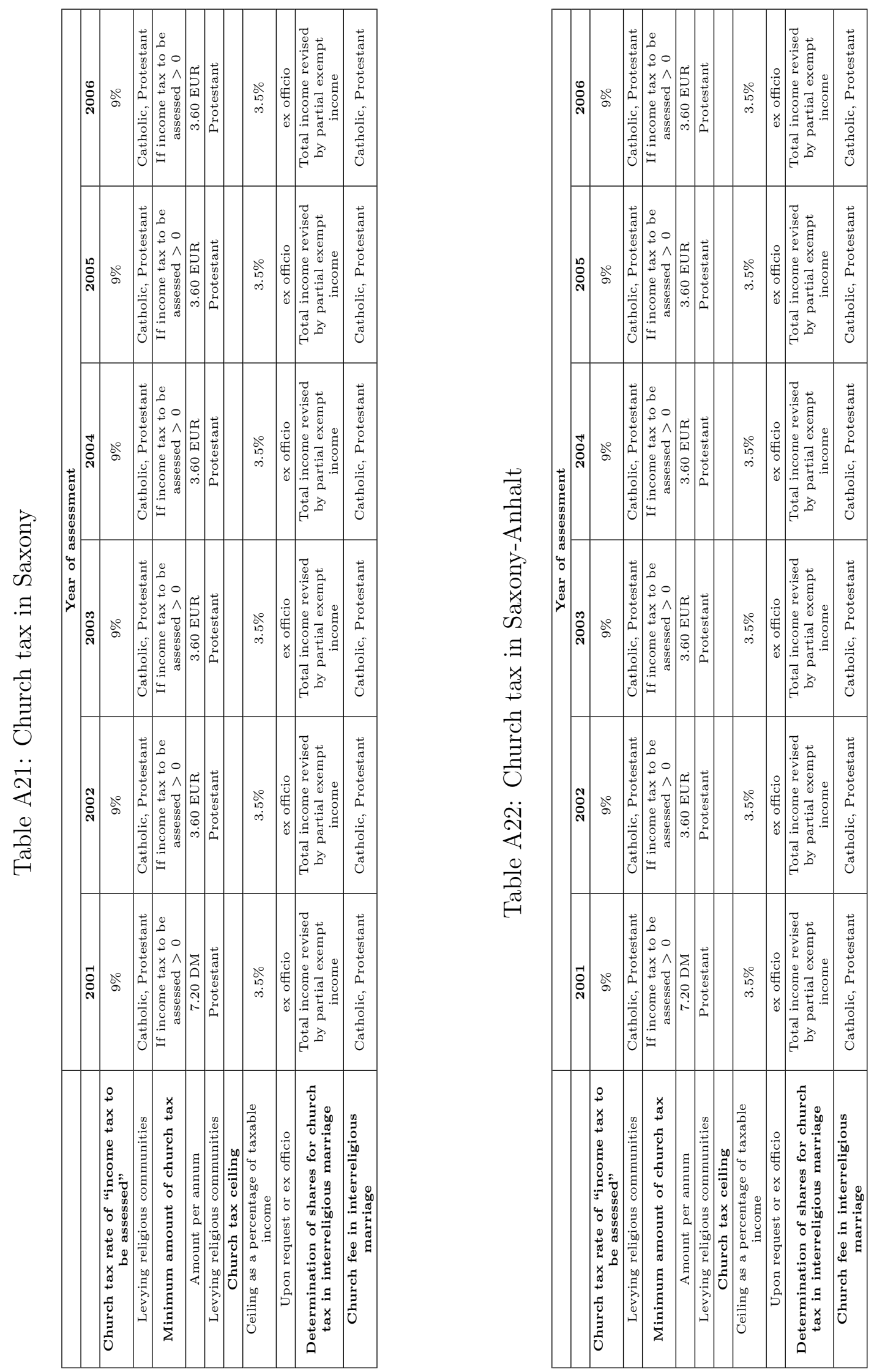

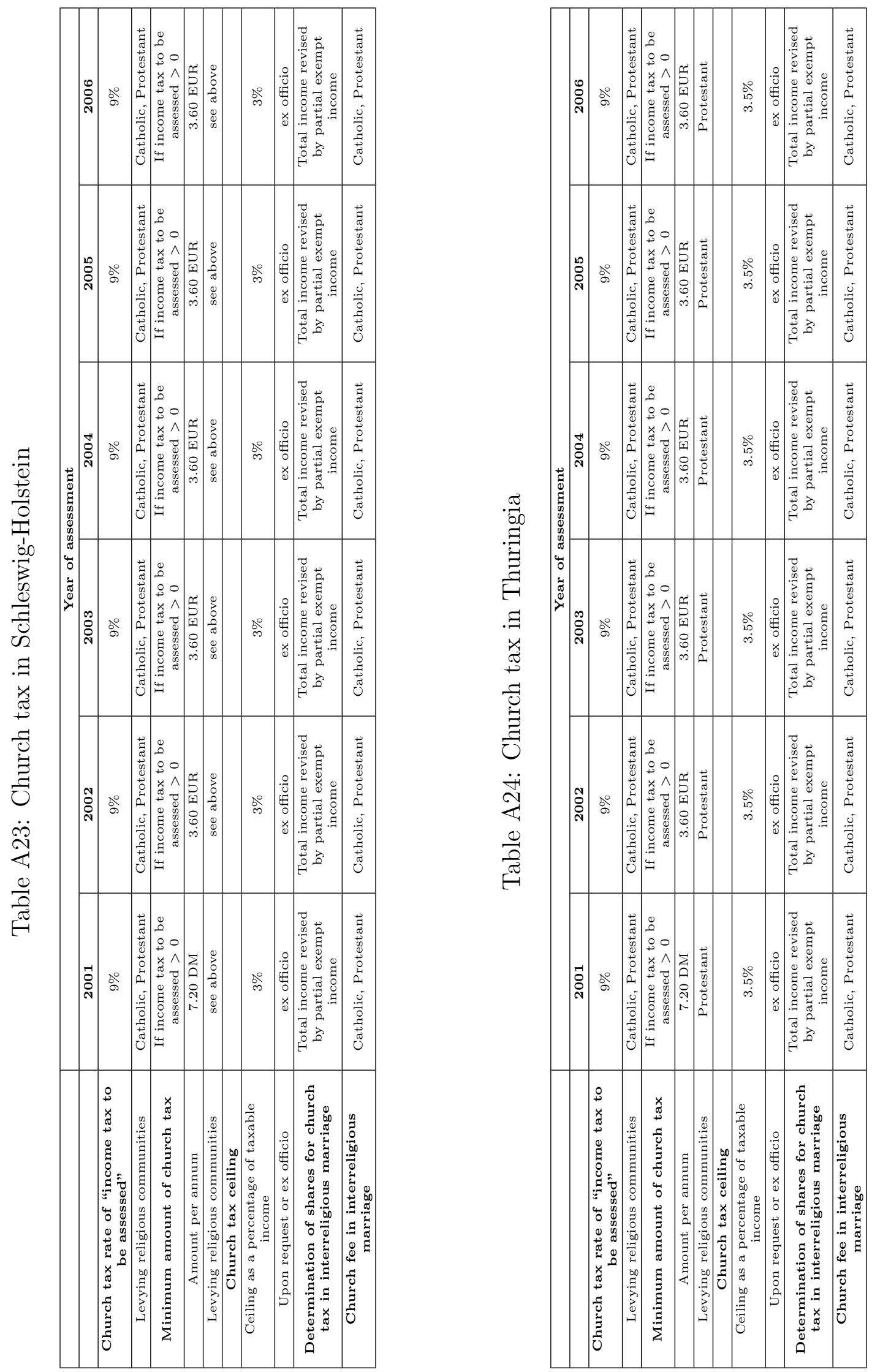

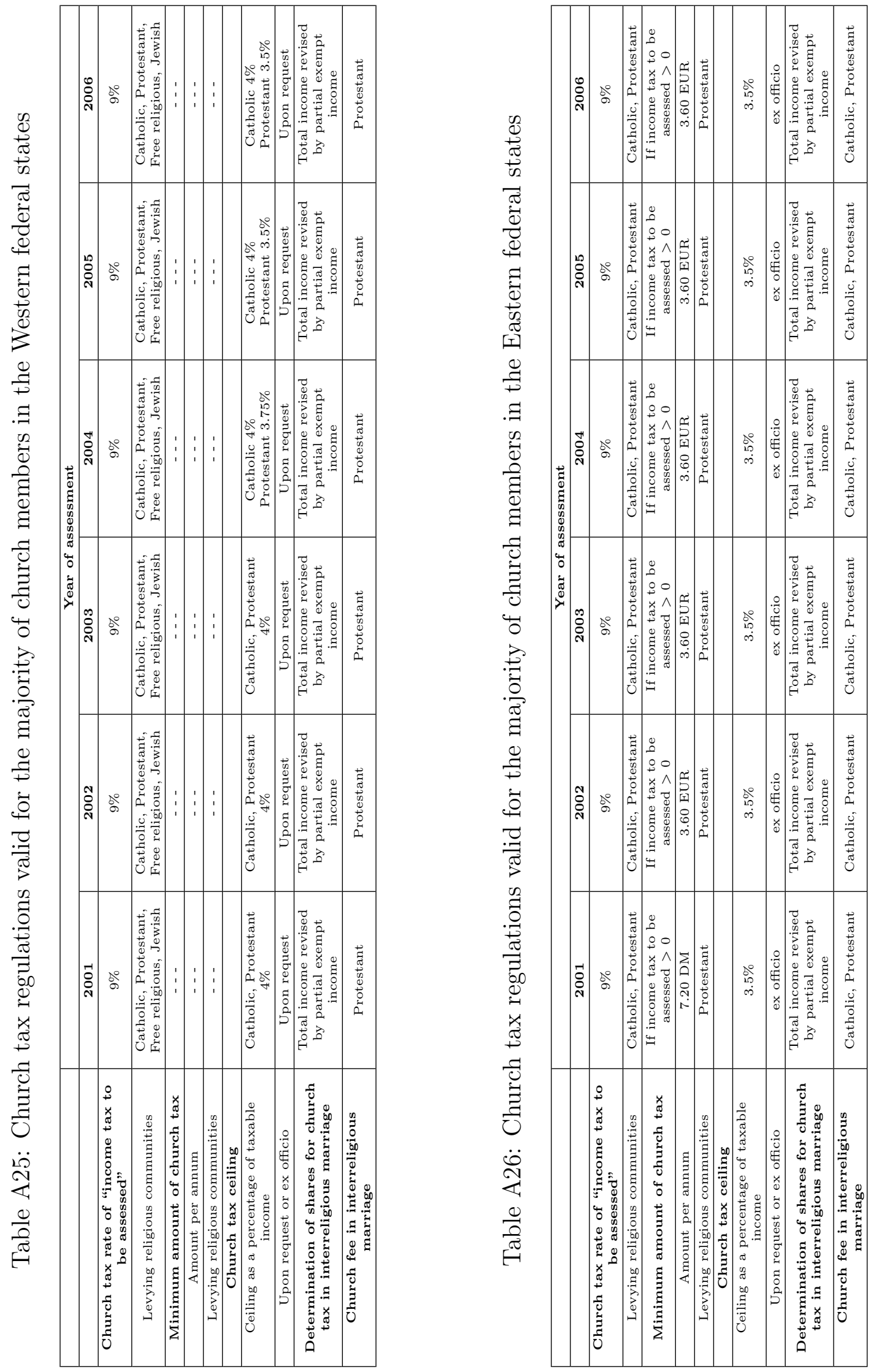


\section{Details for the computation of the church tax}

A marriage is called inter-denominational if husband and wife have different affiliations (e.g. Catholic husband and Protestant wife, Protestant husband and Jewish wife) and both religious communities raise church tax. This is different from the case of interreligious marriages where one partner is subject to church tax and the other partner is not (e.g. Islamic husband and protestant wife). In the case of an interreligious marriage, a comparative calculation between the church tax liability and the church fee in an interreligious marriage is conducted whereby the higher amount of both is to be paid. The intention is that the income of the partner without church tax liability should not be drawn on when assessing the church tax liability of the partner who actually is obliged to pay church tax. The fictitious taxable income of the couple is the assessment base of the church fee in an interreligious marriage.

This appendix shows how the church tax liability is computed in case of inter-denominational and interreligious marriage.

In an inter-denominational marriage, both partners belong to a religious community which raises church tax in the federal state of residence. The assessment base for the church tax liability of each partner is half the joint fictitious income tax:

church tax $=$ fictitious income tax $\cdot 0.5 \cdot$ church tax rate

It may be, however, that for example the religious community of the husband foresees a ceiling for the church tax while the religious community of the wife does not. In this case, the upper limit of the church tax liability is computed as follows:

$$
\text { church tax ceiling }_{\text {husband }}=\text { joint fictitious taxable income } \cdot 0.5 \cdot \text { ceiling rate }
$$

In an interreligious marriage, only one partner is member of a religious community which raises church tax in the federal state of residence. In this case, the church tax liability of this partner is computed as in the following example for the year 2006:

\begin{tabular}{cccc} 
& Husband & Wife & Total \\
\hline $\begin{array}{c}\text { Total income revised by } \\
\text { partial exempt income }\end{array}$ & $€ 50,000$ & $€ 20,000$ & $€ 70,000$ \\
$\begin{array}{c}\text { Income tax liability on } \\
\text { total income in case of } \\
\text { single assessment }\end{array}$ & $€ 13,096.25$ & $€ 2,850.06$ & $€ 15,946.31$ \\
$\begin{array}{c}\text { Share of total income } \\
\text { tax liability }\end{array}$ & $82.1 \%$ & $17.9 \%$ & \\
\hline
\end{tabular}


church tax husband $=$ fictitious income tax $\cdot 0.821 \cdot$ church tax rate

The upper limit of the church tax of the husband would be determined as follows:

\begin{tabular}{cccc} 
& Husband & Wife & Total \\
\hline $\begin{array}{c}\text { Total income revised by } \\
\text { partial exempt income }\end{array}$ & $€ 50,000$ & $€ 20,000$ & $€ 70,000$ \\
Share of total income & $71.4 \%$ & $28.6 \%$ & \\
\hline
\end{tabular}

church tax ceiling $_{\text {husband }}=$ joint fictitious taxable income $\cdot 0.714 \cdot$ ceiling rate

The fictitious taxable income of the couple (i.e. less child allowances and under consideration of partial exempt income) is the assessment base of the church fee in an interreligious marriage which is determined as follows:

Table A27: Church fee in interreligious marriage

\begin{tabular}{|c|c|}
\hline Fictitious taxable income in Euros & Church fee in Euros \\
\hline $30,000-37,499$ & 96 \\
\hline $37,500-49,999$ & 156 \\
\hline $50,000-62,499$ & 276 \\
\hline $62,500-74,999$ & 396 \\
\hline $75,000-87,499$ & 540 \\
\hline $87,500-99,999$ & 696 \\
\hline $100,000-124,999$ & 840 \\
\hline $125,000-149,999$ & 1,200 \\
\hline $150,000-174,999$ & 1,560 \\
\hline $175,000-199,999$ & 1,860 \\
\hline $200,000-249,999$ & 2,220 \\
\hline $250,000-299,999$ & 2,940 \\
\hline 300,000 and more & 3,600 \\
\hline
\end{tabular}

This table displays the regulation valid in the years 2002 to 2006. In 2001, the Deutsche Mark was still the means of payment. How the church fee was determined in that year is shown in Table A28 in the appendix. 
Table A28: Church fee in interreligious marriage in 2001

\begin{tabular}{|c|c|}
\hline Fictitious taxable income in DM & Church fee in DM \\
\hline $60,000-74,999$ & 180 \\
\hline $75,000-99,999$ & 300 \\
\hline $100,000-124,999$ & 540 \\
\hline $125,000-149,999$ & 780 \\
\hline $150,000-174,999$ & 1,080 \\
\hline $175,000-199,999$ & 1,380 \\
\hline $200,000-249,999$ & 1,680 \\
\hline $250,000-299,999$ & 2,400 \\
\hline $300,000-349,999$ & 3,120 \\
\hline $350,000-399,999$ & 3,720 \\
\hline $400,000-499,999$ & 4,440 \\
\hline $500,000-599,999$ & 5,880 \\
\hline 600,000 and more & 7,200 \\
\hline
\end{tabular}

